\title{
Romanization of the western Illyricum from religious point of view
}

\author{
Nenad Cambi \\ Split
}

The Romans likely regarded all of the peoples of Illyricum as belonging to a culturally coherent ethnic group, which they obviously did not. ${ }^{1}$ Since their anthroponomy and toponymy show only small differences between them, it is only possible to differentiate several personal onomastic formulae belonging to northern, middle or southern Illyrian ethnic groups. ${ }^{2}$ However, much bigger differences reveal religious systems and cults among the Illyrian peoples which leads to the conclusion that considerable differences existed on the Balkans area that later belonged to the Roman province of Dalmatia.

The religious aspect is much more important than anything else among cultural phenomena. This is why the Romans tried to absorb the local cults into their religion. Unfortunately, we can only draw conclusions about the indigenous religions on the basis of Latin inscriptions which reveal the phenomenon of Roman interpretation (interpretatio romana ${ }^{3}$ ), since pre-Roman strata

\footnotetext{
${ }^{1}$ As far as I am concerned, this is the reason why this name was given to such a huge region for administrative and practical purposes in the period when the Romans did not precisely know the ethnic and cultural structure of these people. The general name Illyrians could not be attributed to all of them that inhabited this large area.

${ }^{2}$ Rendić-Miočević 1948; Rendić-Miočević 1989, 711-728; Katičić 1962, 95-120; Katičić 1963, 255-293; Katičić 1963, 255-293; Katičić 1964, 23-33; Katičić 1976; Kurilić 2002, 123-148.

${ }^{3}$ Tacitus, De origine et situ Germanorum, 43. Tacitus' passage was many times the subject of scholarly studies. This passage reads as follows: Apud Nahanarvalos antiquae religionis lucus ostenditur. Praesidet sacerdos muliebri ornatu: sed deos, interpretatione Romana, Castorem Pollucemque memorant: ea vis numini; nomen Alcis. Nulla simulacra, nullum peregrinae superstitionis vestigium: ut fratres tamen, ut juvenes, venerantur. English translation (N. Cambi): „Nahanarvali had
}

are almost nontransparent. Only archaeological findings can hint at such conclusions. It is possible to trace the continuity of the god-mother religion in the northern Adriatic area from prehistoric to historical times. ${ }^{4}$

As far as I understand the term, Romanization was a process which covers conveying the local peoples of a province to the Roman way of life. This process is not covered by the term acculturation since the latter does not encompass the political aspect of the process, which is extremely important. The huge Roman Empire was inhab-

a sacred place in their old religion where a priest dressed in woman's robes presides, but in the Roman way (interpretatio romana) they performed the cult of Castor and Pollux there known as Alcis who show the same god's nature (numen). There are no traces of foreign superstitions, they were honored as youths and as brothers". Cfr. Wissowa 1918, 1-49. Wissowa commented this passage so that these German divinities were of the same character. The only difference between German and Roman numina is the difference in names, but the divine nature is in essence the same. Thus Romans everywhere applied a kind of interpretatio Romana. That means that Tacitus, more or less rightly so, recognized some similarities between the religion and essence (numina) of the foreign gods. Tacitus gave them Roman names which the provincial peoples adopted and thus joined them to Roman culture. Sometimes they preserved the local name as a suffix, and sometimes this suffix disappeared over the course of time. This does not matter if for example a certain god was revered in Britain as deus Cocidius, as deus Mars Cocidius, or finally only as Mars, as it is the same god and the difference only serves to reveal three different stages of romanisation. About interpretatio romana cfr. Ferri 1976, 125-133. Ferri's approch to the problem is slightly different since the cults had the same Indo-European roots what was remarked by Romans. Ando 2002, 41-51. The paper of Heinzmann 2012, 117-142.

${ }^{4}$ About this cults in generally Gimbutas 1982 (rep. 2007), 152-196. 
ited by a large number of peoples with different scales of indigenous cultures which were not easy to amalgamate on a sustainable level. This process was encouraged by the Roman central power. The interpretatio was not easy in the beginning, but resistance to the process, particularly in imperial times, diminished and gradually grew into a desire to accept the Roman way of life. The provincial elite were the bearers of these processes and their bilateral progress in local society.

A unique religious system did not exist on the territory of Illyricum before the Romans. Many ethnic entities developed different simple or even complex religious systems demonstrating the different character of their essence. Religion was one of the most important components of their cultures. Typical example of such phenomenon can be noticed among the Histrians, Liburni, Delmatae and indigenous people that lived south of the river Neretva.

Local goddesses bearing different names were revered among the Liburni. Every community had its own, unique goddess (for example Ica, Avitica, Jutossica, Sentona, Latra, Ansotica, etc). ${ }^{5}$ Masculine gods seem to be almost unknown. The same characteristics can be observed among Histrian communities. There were other female goddesses such as Boria, Eia, Iria, Histria, Nebres, Seixomnia, Trita, with analogous religious characteristics to the Liburni. ${ }^{6} \mathrm{~A}$ common feature is that all of them were female divinities differing in their cult properties and competences (numina). Unfortunately, only a small number of monuments show depictions of these goddesses. They reveal some differences in their iconographic manifestations. Avitica from Albona (Labin) is represented as a seated goddess in a long garment with what is likely a cornu copiae (City Museum in Labin $^{7}$ ). The goddess is to the right of the altar, which is decorated by a garland, as in Roman liturgy (Fig. 1). Symmetry would demand another figure to the left of the altar, but this side is not preserved. The inscription does not mention which figure could be there. Under the relief

\footnotetext{
${ }^{5}$ About that compare Medini 1972, 34-36; Medini 1984a, 7-32; Šašel Kos 1999, 75-80.

${ }^{6}$ Jurkić 2005, 39-47; Šašel Kos 1999, 63-67.

${ }^{7}$ Jurkić $2005,121,1$. 1. The depiction is too small so the object is hard to accurately describe, but it is wider on the top and it comes to the hip of the seated figure. So the horn of plenty is almost certain.
}

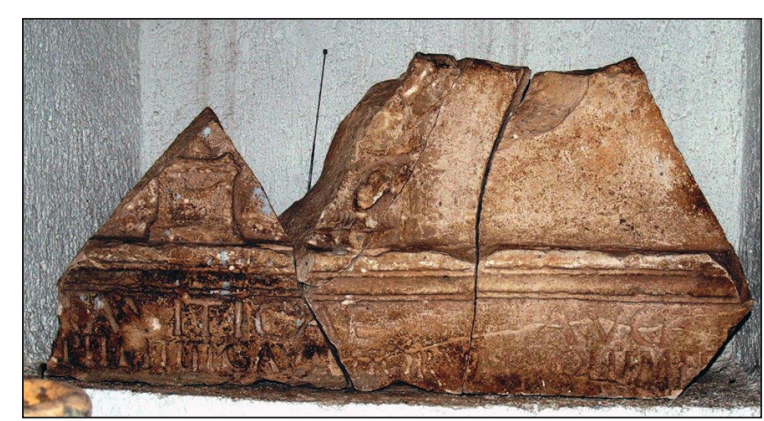

Fig. 1. The relief of Avitica from Labin

panel there is partially preserved inscription: $A v$ iticae Avg(ustae)/.... T(iti) Gavili(orum) (servus) Voltimes. Significantly, the monument was dedicated by the servus of the city elite Gavilii who still had the Liburnian name Voltimes(is), which points to his Liburnian origin. ${ }^{8}$ The Gavilii were an autochthonous Liburnian family that was romanized early. ${ }^{9}$

Latra from Nedinum was represented as a standing figure in long robes with a scarf on her head, covering her hair (Fig. 2). In front of her is an altar bearing the letters: L(ibens)Lat(rae) $\mathrm{M}$ (erito). ${ }^{10}$ The relief is very primitive, as is the epigraph, but the iconographic idea is clear enough.

So there are two iconographic variants of Liburnian goddesses. The first is depicted as a seated goddess on her throne, dressed in long garments (Auitica), and the second standing ( $\mathrm{La}$ tra) in the same type of dress. Their difference in posture does not matter in terms of religion. Both of them are mother goddesses that grant agricultural fertility.

However, Auitica's and Latra's iconographic features are completely different compared to Anzotica, the Aenona goddess represented as the very well known Roman Venus, revealing nude breasts and small, bearded effigy of Priapus (Fig 3), now in the Archaeological Museum of Split. ${ }^{11}$ It is clear that Anzotica is more important than her son Priapus whose Liburnian name is unknown. It is quite uncommon that Priapus did

\footnotetext{
${ }^{8}$ Mayer 1957, 362-363; Šašel Kos 1999, 75-76.

${ }^{9}$ Cfr. Wilkes 1969, 312 Gavilii probably were colonists from Aquileia. Those bearing local names were obviously slaves or freedmen.

${ }^{10}$ CIL III 15042, Medini 1984b, 223-243, Pl. II, 1.

${ }^{11}$ Cambi 1980, 273-278.
} 


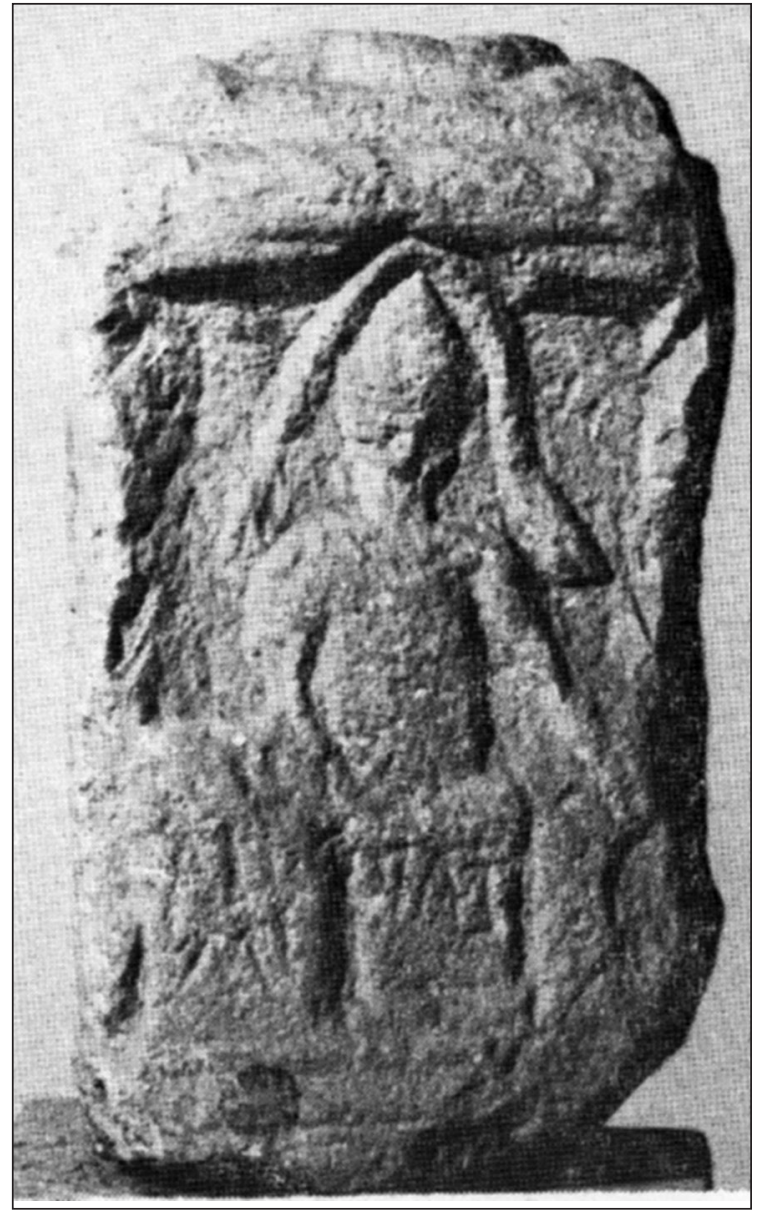

Fig. 2. Latra's relief from Nadin

not develop cult in Liburnia later. ${ }^{12}$ One of two epigraphs reveals that the iconographic characteristics of the goddess were adopted for the local Anzotica. ${ }^{13}$ The first epigraph records the name, the pronunciation of which was obviously different (Andzotica). Over several decades, Anzotica became Ansotica. ${ }^{14}$ The first inscrip-

\footnotetext{
${ }^{12}$ As far as I know, there is no epigraph dedicated to Priapus or his image in Liburnia. But there is evidence of Priapus in Dalmatia, in the form of a fragmented statue in the Archaeological Museum of Split (Fig. 4).

${ }^{13}$ Année épigraphique 1938, 31; Suić 1969, 26, Pl. XXI, 1. The inscription is as follows: $\mathrm{T}($ itus) Appvleivs $\mathrm{T}(\mathrm{iti})$ 1(iberti) 1(ibertus) Antigonvs

Anzoticae

$\mathrm{V}$ (otvm) S(olvit)

${ }^{14}$ This inscription (Année épigraphique 1940,6) runs as follows:

Veneri Ansotic(ae)

Sacrvm

Baebia C(ai) F(ilia) Maximil

la ex testament(o)

L(uci) Corneli Bassi fecit
}

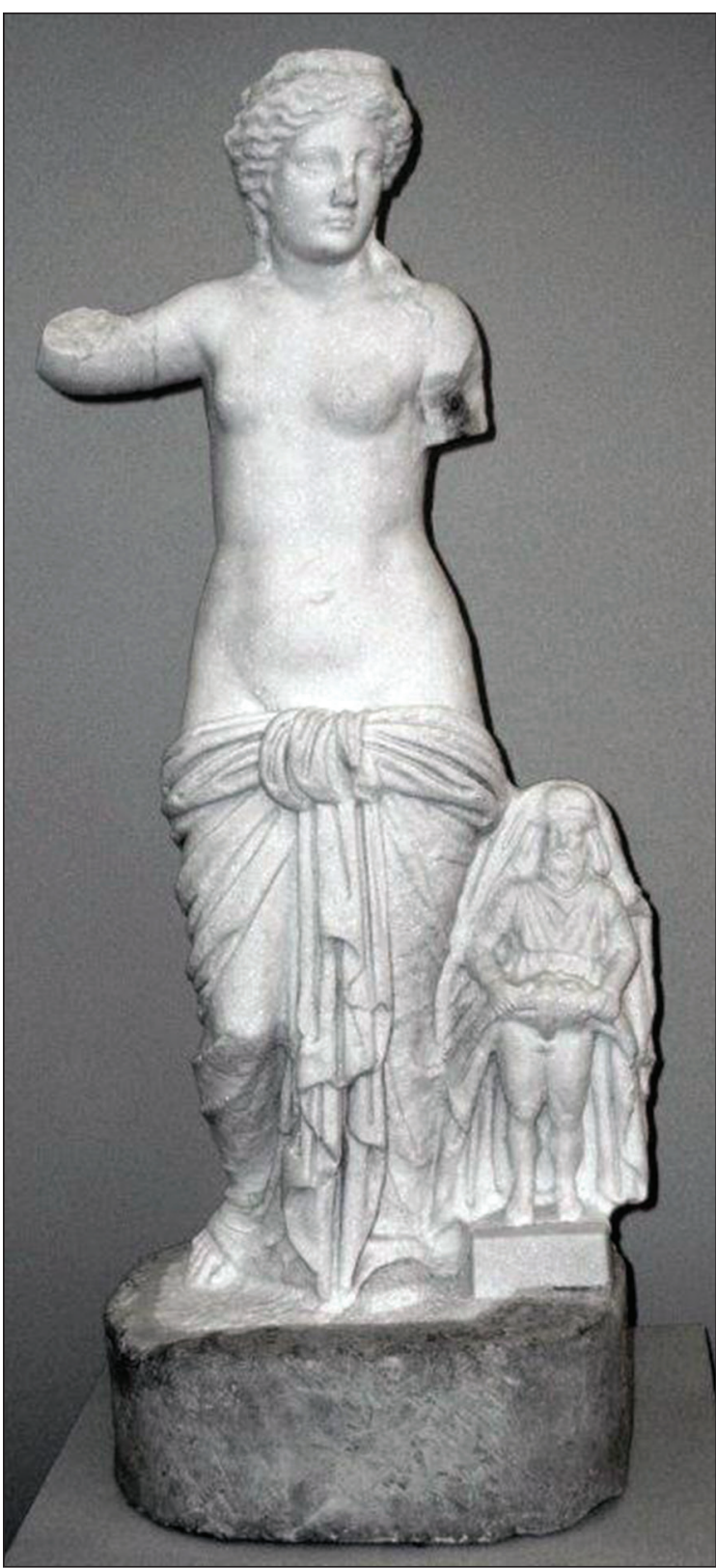

Fig. 3. Venera Anzotika Archaeological Museum Split (AMS)

tion shows that T. Apulleius Antigonus, a libertus of a certain Titus, was also a freedman. All the mentioned names bore cognomina and belonged to the modest social stratum. One of the liberti had the oriental cognomen Anticonus. However, it was not unusual that foreign people would adopt local cults, particularly belonging to the creed of their patrons. This first epigraph should be earlier than the second (the first decades of the $1^{\text {st }}$ century $\mathrm{AD}$ or the second quarter of the same century). On the other hand, the second in- 


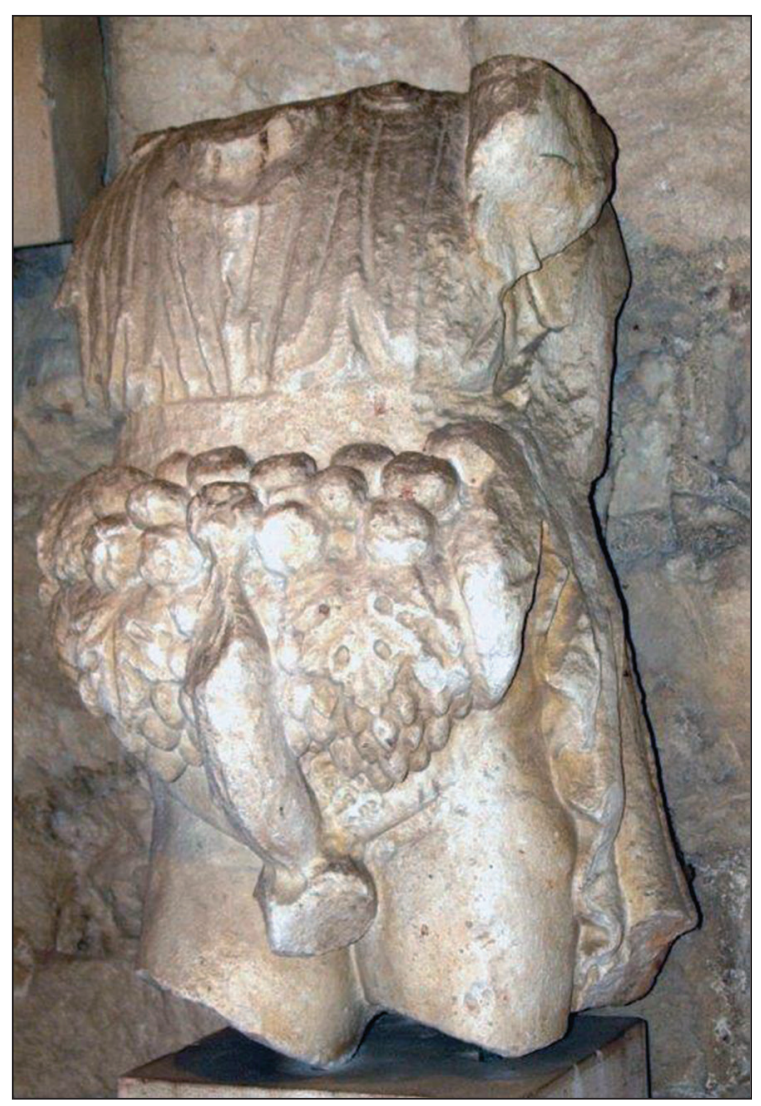

Fig. 4. Priapus statue from $A M S$

scription is dedicated by local highly Romanized people who were already Roman citizens, having their tria nomina onomastic form. The statue belonged the second inscription, although both were found on the same site where there should have been a small temple (outside the town). ${ }^{15}$ The identification of Ansotica and the Roman Venus is linked with the Histrian Iria from Jasenovik (near Pula), since both divinities syncretized with the same Roman goddess. ${ }^{16}$ Obviously, this goddess was similar in character and iconography with the Liburnian Ansotica, despite their different names. Priapus, the god of fertility, together with Venus, shows their common agricultural character which is symbolized by the fruits in his robes.

Although the Liburnian pantheon was composed primarily of female characters, it's very likely that these goddesses, except Anzotica, were more or less of the same religious character and had not developed into a religious sys-

\footnotetext{
${ }^{15}$ Abramić 1940, 174. The building was not excavated although the remains of architecture were found.

${ }^{16}$ Jurkić 2005, 128, 1. 6.
}

tem, according to preserved archaeological evidence. They were supreme goddesses, acting like mothers of the civitas and the surrounding terrain which were recorded in several inscriptions among the Histrians (Histria Terra).${ }^{17}$ Given the close relations between the Histrian and Liburnian religions, it is strange that there were no dedications to the goddess Terra (for example Liburnia terra). Obviously, the Histrians had a higher sense of national consciousness and identity than the Liburnians, who were developing along more communal lines (Aenona, Asseria, Nedinum etc). Unlike the Liburnians, the Histrians had a kind of local Histrian federation of communities, the center of which was in Nesactium, which was crushed by the Romans. ${ }^{18}$ Their last king, Epulo, committed suicide in $171 \mathrm{BC}$. Such a federation never existed on the Liburnian territory. This is the consequence of their higher range of ethnic development. ${ }^{19}$ An altar from Bigeste, in what is Herzegovina today, is dedicated as an altar of Terra Hillyrica (not Delmatica), which is more precise in terms of Roman administration. ${ }^{20}$ It is very significant to note that the inscription on this altar also mentions Jupiter, so it is very likely that Terra Hillyrica is rather divinized administrative, and not ethnic, term.

The Japodes in the western Illyrian hinterland (on the northern side of the mountain Velebit and the border of Pannonia) were not transparent enough in their original religious essence. ${ }^{21}$ The only Japodian known to us is Bindus, the god of water and fountains, who was assimilated with Roman Neptunus. The cult centre of this divinity was discovered in the valley of the river Una, near Bihać (Privilica).22 Bindus, according to current evidence, was not known in other parts of Japudia. This altar was dedicated by Proculus Parmanicus (Fig. 5). ${ }^{23}$ Another altar is of Titus

\footnotetext{
${ }^{17}$ Cfr. Jurkić 2005, 125, 1. 5; 126, 1. 5. 2 (Histria Terra) 126, 1. 5.3 (Histria); 127, 1. 5. 4 (Istria); This godess about cfr. Šašel Kos 1999, 68-69.

${ }^{18}$ Matijašić 2009, 99-113.

${ }^{19}$ About this process Matijašić 2009, 41-47.

${ }^{20}$ Iscriptiones Latinae 1963, 1915; Šašel Kos 1999, 67.

${ }^{21}$ About Japodes their religion and arts cfr. Raunig 2004; Olujić 2007.

${ }^{22}$ There are several inscriptions. About these altars cfr. Raunig 1972; Cambi LIMC VIII, 1, s. v. Neptunus-Bindus 500; Katičić, 1995, 157-160; Kukoč 2009, 235-248 figs 359-362.

${ }^{23}$ The inscription (CIL III 14325) runs as follows: Bindo Neptuno
} 


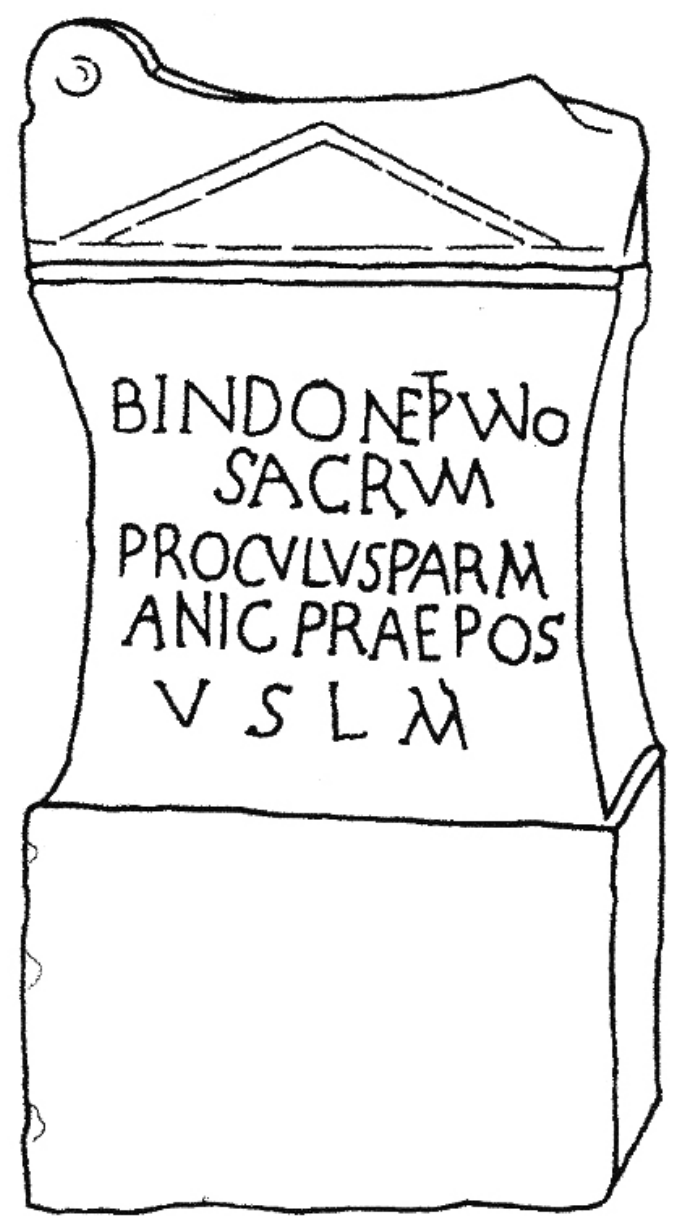

Fig. 5. Altar dedicated to Bindus Neptunus by Proculus Parmanicus

Loantius Rufus praepositus Japodum (Fig. 6). Votum is surely dedicated to Bindus, although the epigraph does not mention that, since it was discovered on the same site. ${ }^{24}$ All of the mentioned inscriptions fortunately complete each other, and the three people were praepositi of the Japodes (a kind of local chieftain). The first praepositus had an anomalous name: Proculus Parmanicus. Both of them are cognomina, and while Proculus is Latin, Parmanicus is obviously an epichoric name.

\section{Sacrum}

Proculus Parma

nicvs praeps(itus)

$\mathrm{v}$ (otum) s(olvit) l(ibens) $\mathrm{m}$ (erito

${ }^{24}$ This epigraph (CIL III 14328) is as follows: T(itus) Loantius

Rufus

Praepositus

Japodum

$\mathrm{V}$ (otum) s(olvit) l(ibens) m(erito)

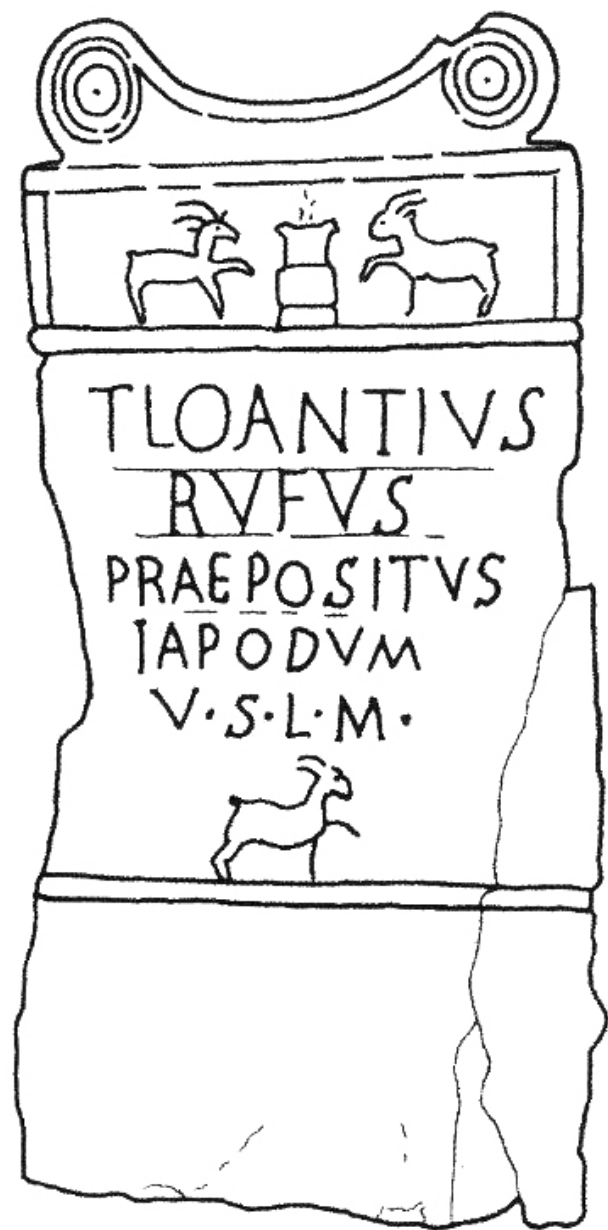

Fig. 6. Altar probably dedicated to Bindus Neptunus by Loantius Rufus

The other altar was also dedicated by a praepositus who had Latin tria nomina T(itus) Loantius Rufus. Although it was not specified whose praepositus the person was, he was undoubtedly Japodian. This might mean that Bindus had already become Neptunus, but we cannot say for certain. The third altar clearly depicts the iconography of Neptune on one and Triton on other side. Obviously, Neptune's iconography (attributes: fish and a scepter) was also well suited to Bindus (Fig. 7). ${ }^{25}$ On the other hand, the iconography of Triton (mixed creature of fish and man) belongs to Neptune's religious world. The male goats represented on both sides of the altar in the gable, and another below the inscription, are a hint to the very popular practice of sacrificing this animal in the long centuries of the ancient periods. ${ }^{26}$ This

\footnotetext{
${ }^{25} \mathrm{Cfr}$. the inscription CIL III 14324.

${ }^{26}$ Iliad, 21, 132, 23, 146, Oudyssea, 11, 727.
} 


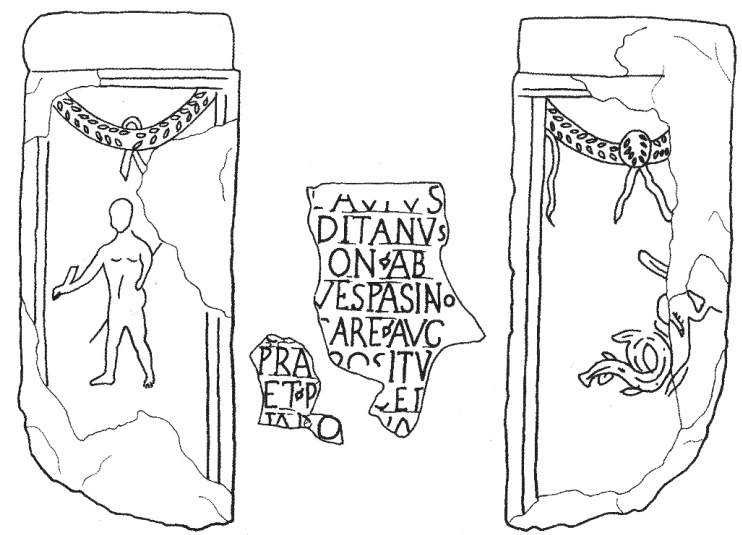

Fig. 7. Altar of Bindus Neptunus

indicates that a more or less complete water pantheon existed with the Japodians. A Roman iconographic influence is evident, but it corresponds to the Japodian notions of the god. The process of the Romanization of the Bindus religion lasted through the $1^{\text {st }}$ century $\mathrm{AD} .{ }^{27} \mathrm{~A}$ very important question arises: was the main sanctuary of the Japodes located at Privilica? The three dedications of the praepositi Japodum or praepositi and principes, would hint to such a supposition, but it is far cry from proof since the proper role of these two functions is not quite clear. Were they chieftains of a larger Japodian territory or only of the community at Privilica in the vicinity of Bihać? According to parallels among other Illyrian peoples, similar titles belonged to the high functionaries of smaller communities. ${ }^{28}$ Bindus was likely not the only Japodian god, but this water god, like the Roman Neptune, had his own thiasos. The existence of other water sanctuaries is very probable, but unsupported. The sanctuary at Privilica was certainly very important since it was built into a temple. ${ }^{29}$

On the contrary, the Delmatae, the southeastern neighbors of the Liburni and Japodes had quite a different religious system, in which Silvanus and Diana were the main divinities. The names Silvanus and Diana prevailed after the end of the process of Romanization (interpreta-

\footnotetext{
${ }^{27}$ The inscription CIL III 14324 mentions a donation to Titus Flavius ..... ditanus of the emperor Vespasian (69-79 $\mathrm{AD})$.

${ }^{28}$ For example princeps municipii Riditarum Cfr. RendićMiočević 1989, 872-890.

${ }^{29}$ Cfr. CIL III 14327.
}

tio Romana)..$^{30}$ Unfortunately, their indigenous names are unknown, but many sources speak in favor of their original Dalmatian provenience.

The main god was Silvanus, ${ }^{31}$ and his female pair (not wife) was Diana. ${ }^{32}$ The constituent part of this system were the Nymphae (Silvanae, Fontanae, Salutares, etc.), which were the bearers of natural forces, abundance, and health. Together they formed part of a more developed religious system of nature (woods, fountains, fauna, growth, agriculture etc). The main problem is whether Silvanus is an indigenous Delmatian god or the Italic Silvanus. ${ }^{33}$ On the other hand, all Croatian scholars are of the opinion that Silvanus was an autochthonous god that was syncretized with the Italic Silvanus. ${ }^{34}$ This discussion remains unfinished, but in my opinion, the Roman Silvanus had no influence in the religious content or iconographic features of the Silvanus known in central Dalmatia. The Romans offered only the name to the god (not the iconography). In my opinion, the case of Silvanus is an instructive example of Tacitus' interpretatio Romana, and also of its reversible process, interpretatio indigena. ${ }^{35}$

The iconography of Silvanus, Diana and the Nymphae developed in Dalmatia under Greek, not Roman, influence. When the Delmatae came to the littoral (the area between Tragurium and Epetium), Salona soon became the main port of this area for commerce and communication to the inland. The Delmatae were the closest neigh-

\footnotetext{
${ }^{30}$ Cfr. note 3. In Croatian archaeological literature this term was used very often. Cfr. Rendić Miočević 1989, 432; Rendić-Miočević 1989, 461-465; Rendić-Miočević / Šegvić 1998, 7-11; Rendić-Miočević 2003, 408-419. These problems also were studied by other authors.

${ }^{31}$ About the iconographic repertory of Silvanus, Diana and Nymphs cfr. von Schneider 1885, 37-46; Schneider's system was elaborated by Rendić-Miočević 1989, 469-479 (Silvanus alone), 479-488 (Silvanus and Nymphs), 488-496 (Silvanus with other gods), 496-501 (Silvanus and Nymphs and other gods).

${ }^{32}$ Diana was depicted alone, together with Silvanus and the Nymphs, and with official Roman gods. Diana alone never appeared with Nymphs. Nymphs are always followers of Silvanus.

${ }^{33}$ Some scholars do not share the opinion of the indigenous origin of Silvanus in Dalmatia. Cfr. Dorcey 1992, 68-70; Nagy 1994, 763-773.

${ }^{34}$ Cfr. note 33

${ }^{35}$ Ferguson 1974, 214-220. The author calls such a process interpretatio Celtica. The indigenous peoples gladly accepted the Roman interpretation after a certain period.
} 
bors of the Greek settlements on the islands (Issa and Faros), and on the coast (Tragourion and Epetion). The Greek merchants had trade relations with the hinterland. In such contacts, the iconography of the Delmatae main god with mixed features (of a man and male goat) borrowed the image of the Greek Pan, although the latter was not a direct religious pair. ${ }^{36}$ This identification with Silvanus occurred after the interpretatio graeca of the Delmatean god, who logically had his Dalmatian (unknown) name. ${ }^{37}$ The Greek name Pan was not clear enough for Italic settlers, soldiers and merchants who inhabited these parts of Illyricum a century or so later. Salona, as the main port of the Delmatae, was in the close vicinity of the Greek settlements, unlike the other parts of Illyricum. ${ }^{38}$ The syncretistic process developed there over several centuries. From there the iconography expanded into other parts of the Delmatae territory, even more deeply inland, where the indigenous religion was also very popular. That is the reason why the Greek Pan became the artistic model for the Dalmatian Silvanus, even before Roman penetration. The Italic Slivanus was completely different, and his image was unknown in Dalmatia in the early period of Roman penetration. ${ }^{39}$ So, Silvanus, together with Diana and the Nymphae Fontanae, Silvestres or Silvanae, is depicted on many reliefs from the $1^{\text {st }}$ century AD. The mixing of the peoples caused an acculturation process which was not limited to the local population, since it also became popular among newcomers of various kinds. All of the above mentioned confirms the role of Salona, which is evident from the presence of the largest number of Silvanus, Diana and Nymphae epigraphic and other (sculptural) monuments.

Sometimes Silvanus was depicted alone. Such an example is a fine relief from Libovac near Salona (in Archaeological Museum Split)..$^{40}$ The image is almost a copy of Pan's image (the human torso and arms, bearded head, male goatlegs and an erect penis). Behind him there is a

\footnotetext{
${ }^{36}$ About Pan Herbig 1949; Borgeau 1979; N. Marquardt 1995. The Pan iconography stems from Greek influence, while the interpretatio Romana renamed Pan into Silvanus without changing the religious essence and the iconography. ${ }^{37}$ Cfr. Rendić-Miočević, Silvan 1989, 466-468.

${ }^{38}$ Cfr. Strabo VIII, 5, 5.

${ }^{39}$ About Italic Silvanus Simon 1990, 200-205 (s. v. Silvanus). ${ }^{40}$ Bull. Dalm. XXXIX, 1916, 25; Rendić-Miočević Silvan 1989, 471, Pl. LXXIX.
}

large figure of a male goat (Fig. 8). This figure, as well as a Silvanus relief from Salona that was built in (the destroyed) house Mikelić, are artistically fine reliefs (Fig. 9). ${ }^{41}$ A high-quality limestone relief of Diana hunting (in the movement of taking an arrow from the quiver), known for its classical iconography but unfortunately fragmented, is also from Salona (Fig. 10). ${ }^{42}$ These reliefs are on the same level as, or are even much better than, other Roman cult images. They were probably executed in the same Salonitan workshop. The reliefs of Silvanus and Diana are evidence of their own cult, though they might be images dedicated in the same sanctuary.

However, Silvanus and Diana were rather often shown together indicating that they belonged to the same religious complex. A fine example of the cult unity is a relief executed in the rock near the Roman colony Aequum, now taken out from the rock, which is kept in the Archaeological Museum of the Franciscan monastery in Sinj (Fig. 11). ${ }^{43}$ Many reliefs depict Silvanus and the Nymphs. The iconography of the Nymphs shows their character, function and service in the same religious system: one group shows an oak leaf or a small tree (Nymphae Silvanae or Silvestrae) in their hands (Fig. 12), while the other group holds reeds (Fig. 13) or some other water objects such as shells (Nymphae Fontanae, Fig. 14). ${ }^{4}$

Silvanus and the Nymphs constituted a religious unity together. Silvanus was on the top of this system. The Nymphs dance to Silvanus' music (syrinx) as is depicted on a very instructive relief from Klis (Fig. 15). The Nymphs obviously had their own divine essence (numen), but they acted on Silvanus' music. Diana was also added to this entity, as is shown on some reliefs. ${ }^{45}$ The influence of Silvanus expanded as far as the Pannonian territory. Silvanus is depicted seated on a rock while playing his syrinx. The Nymphs are

\footnotetext{
${ }^{41}$ Cambi 2013, 26, Fig. 14.

${ }^{42}$ To my knowledge, it is not published. It is displayed in the southern part of the portico of the Archaeological Museum of Split.

${ }^{43}$ Abramić 1952, 323, Pl. VI; Cambi 2005, 186, Fig. 186. ${ }^{44}$ Nymphae with shells cfr. Religions and Cults in Pannonia, 64, br. 33; Maršić 1997, 103-124, Fig. 1-7. Nymphae appeared without Silvanus at Varaždinske Toplice, unlike on the arae from Topusko (Vidasus -Thana-Silvanus). It is curious since Topusko was renowned for its hot and healing spring, even in ancient period.

${ }^{45}$ Cambi 2013, 19-20, Fig. 5.
} 


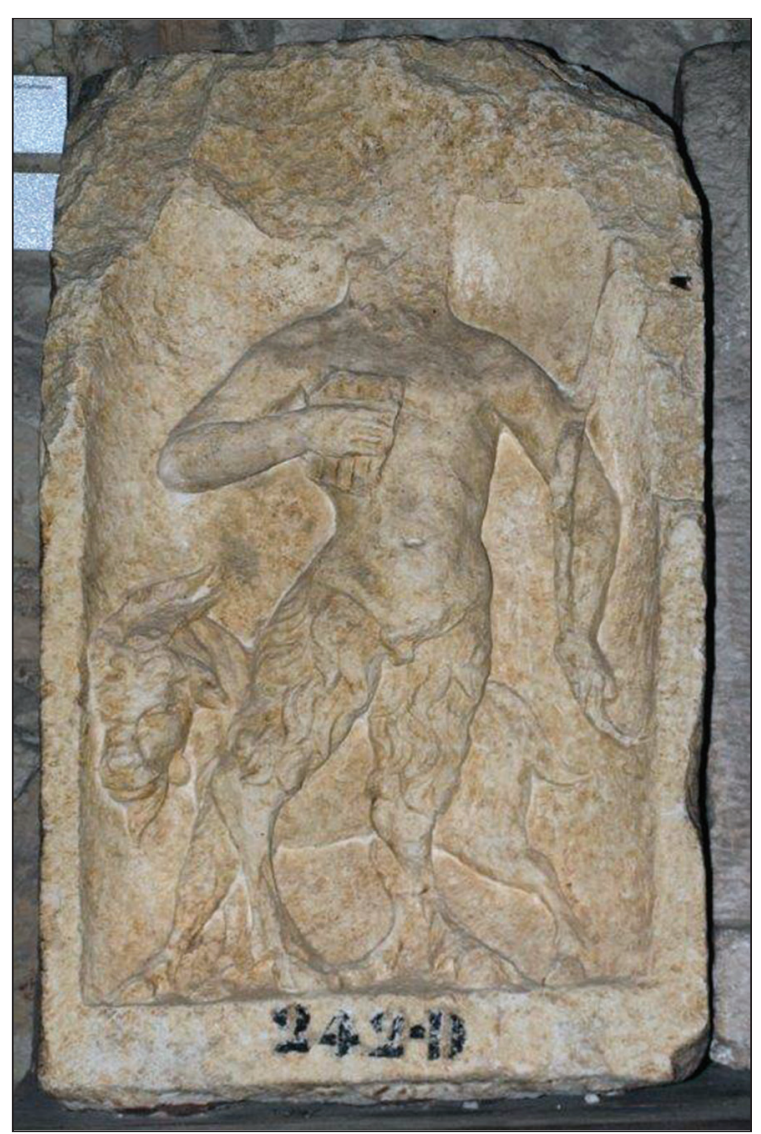

Fig. 8. The relief of Silvanus from Salona

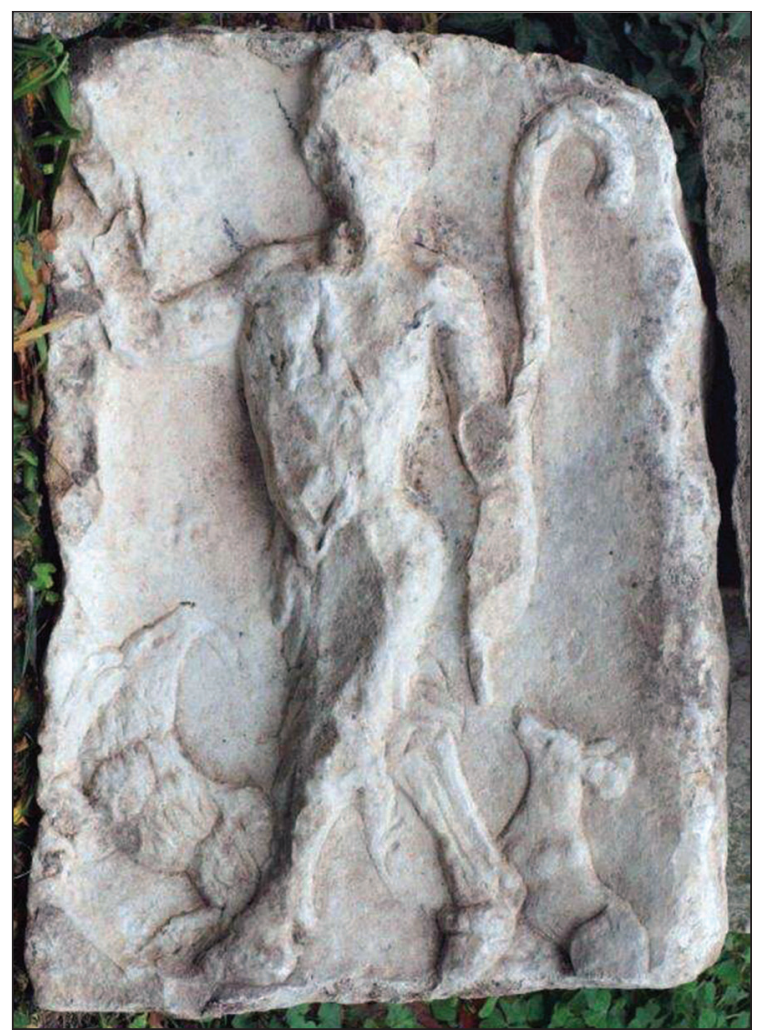

Fig. 9. Silvanus relieffrom Salona (ex Mikelićs house)

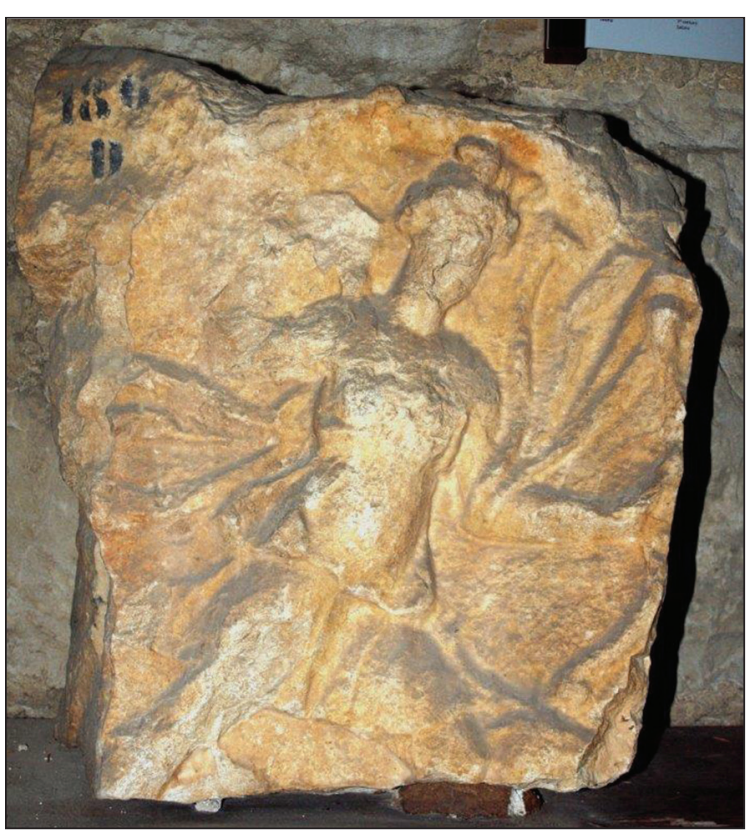

Fig. 10. Diana’s relief from Salona

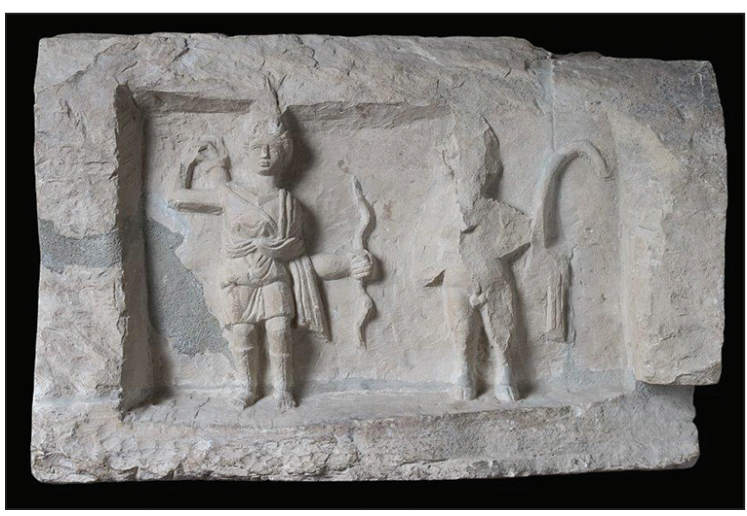

Fig. 11. Diana and Silvanus from Aequum

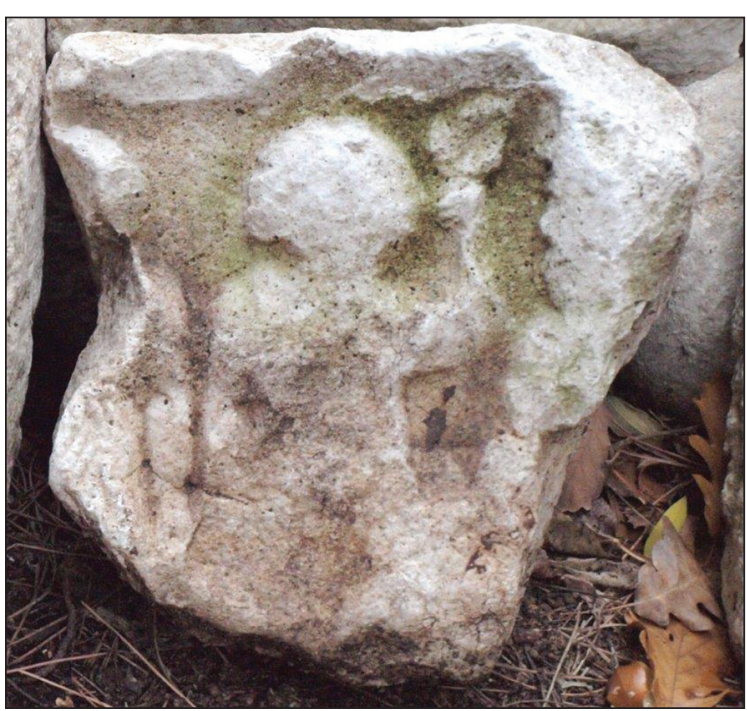

Fig. 12. Nimfe Silvanae. Knin vicinity 


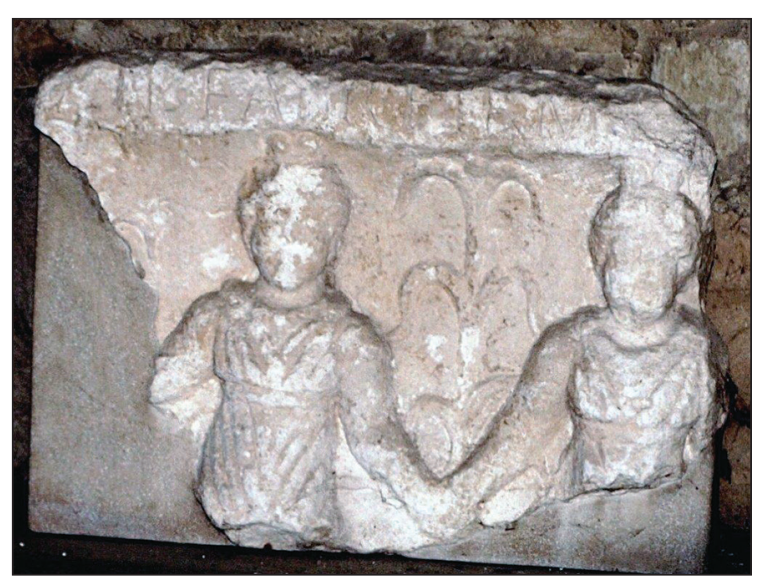

Fig. 13. Nymphae Fontanae, Salona

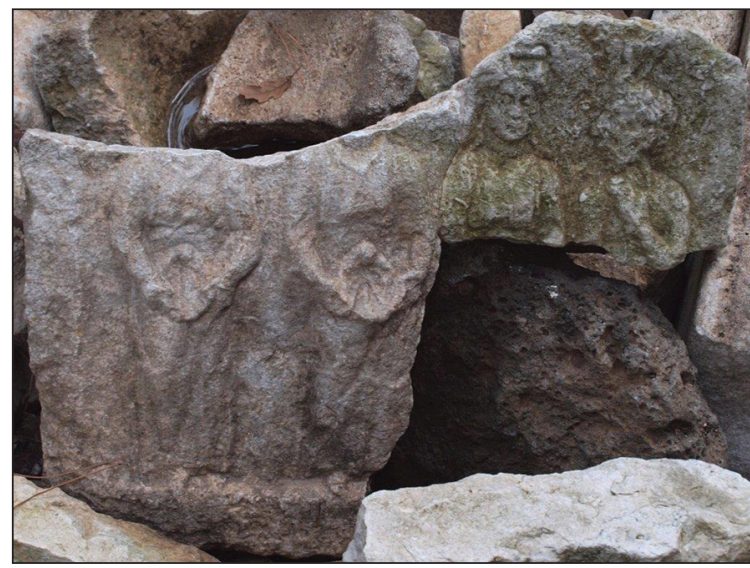

Fig. 14. Silvanus and Nymphae with shells. The vicinity of Knin

dancing (the first and third hold handkerchiefs) and holding each other's hands. ${ }^{46}$ The relief demonstrates that Silvanus belonged to a circle of his divine creatures to whom he gave the rhythm of their movement. The Nymphs were subordinate to Silvanus. They were in charge of the natural cycle of the forests, waters and vegetation. The syrinx in Silvanus' hand indicates that his music, simple and pastoral, moves natural forces. ${ }^{47}$ Two groups of three Nymphs are always depicted separated: three of them as Fontanae, and three of them Silvanae or Silvestres. One very significant characteristic is that the Nymphs are usually depicted together with Silvanus, never alone, unless a group of three women from Opačići near Glamoč (one on the statuary pedestal) are

\footnotetext{
${ }^{46}$ Rendić-Miočević 1989, 481-482, LXXXV, 1.

${ }^{47}$ A very interesting hypothesis was put forward by Selem $2005,425-431$. Selem assumed that the relationship between the indigenous and oriental religions was cosmic music.
}

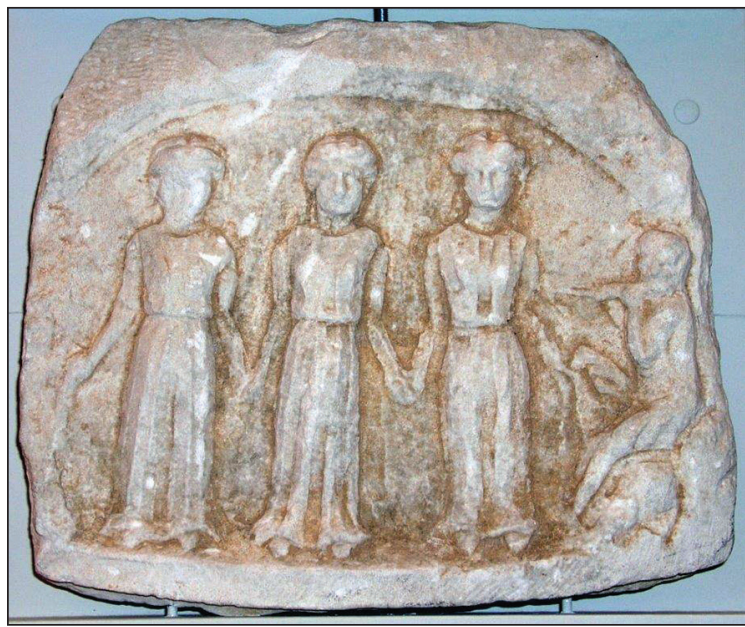

Fig. 15. Silvanus piping und Nymphae dancing, Klis

not Diana and Nymphs (Fig. 16). They are represented without attributes as adherents of $\mathrm{Di}$ ana, but the goddess, on the other side, has trees and a two-handled water jug. The other relief shows Silvanus and Diana (Fig. 17). The two reliefs from Opačići (one certainly of Silvanus and Diana) were the products of the same hand, and very probably belonged to the same sanctuary. ${ }^{48}$

There is a very significant inscription that sheds more light on the Delmatae religion and its relation to the Roman one. This epigraph mentions the reconstruction (from the foundations) of Jupiter's temple with his consentio (harmony) deorum dearumque, Silvanus with Nymphae Fontanae, and Silvanus with Nymphae Silvestres. ${ }^{49}$ The inscription was found in the vicinity of Klis, and is now in the Archaeological Museum of Split (Fig. 18).$^{50}$ This inscription is very important since it demonstrates how a local system was included in the Roman's Jupiter religion, namely in the same consentio deorum dearumque. This means that Silvanus, along with the Nymphs,

\footnotetext{
${ }^{48}$ Rendić-Miočević 1989, 549-550, Pl. LXXXVII, 1, 2; Imamović 1977, 324, no 26, Fig. 26, 336, no 47, Fig. 47.

${ }^{49}$ The inscription was discovered during excavations of the early Christian church at Klapavica near Klis. Cfr. Bulić 1907, 118; Alföldi 1969, 118, 159; Rendić-Miočević 1989, 480; Šašel Kos 1993, 204, no 2 and 207; Zaninović 2007, 205-206.

${ }^{50}$ The inscription is as follows: Im]perio Domini Iovis

Op]timi Maximi ivssit sibi aedem cvm svo Consentio Deor(um) Dearv[mque?

S]ilvestri(u)m Nymphis Fontanis cvm Sil[vano Nymphis Silvestrium cvm Silvano Fe[.....

]nia Astice cvm svo pare conivgi et

Favsto VI et Avg(ustalis) a solo restituit
} 


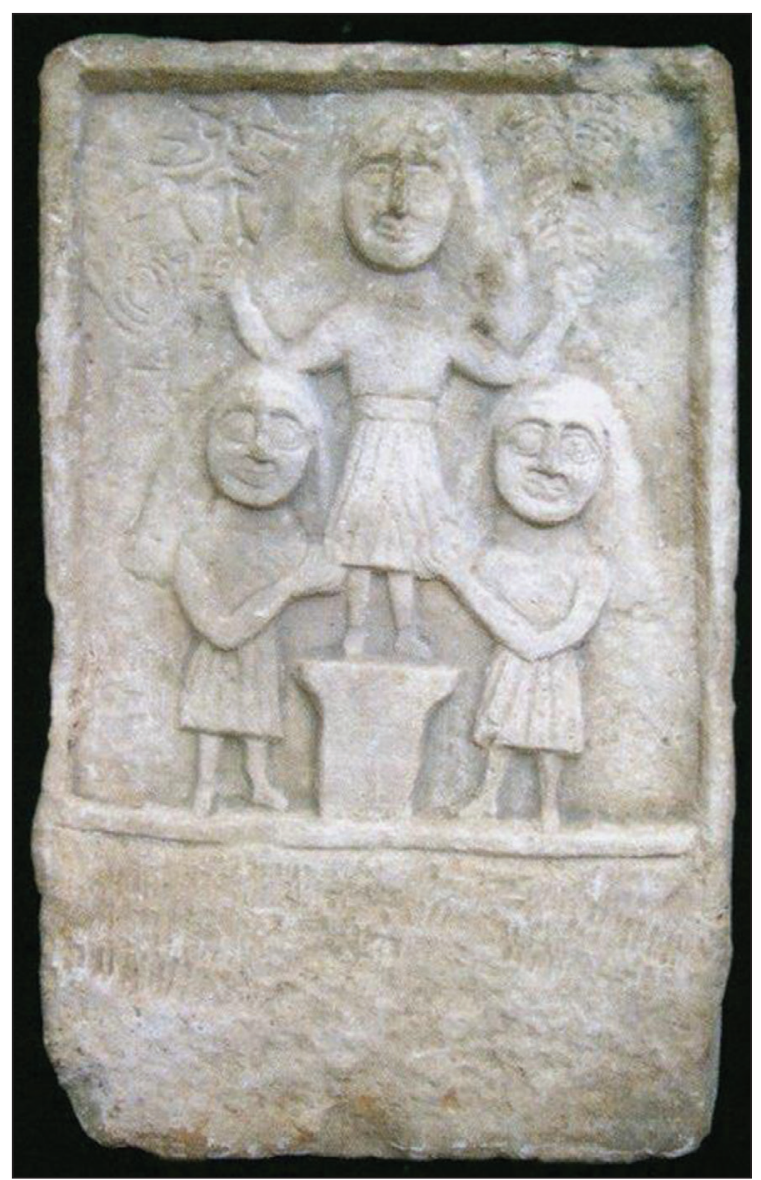

Fig. 16. Diana and Nymphae or Adorants, Opačići, Bosnia and Herzegovina

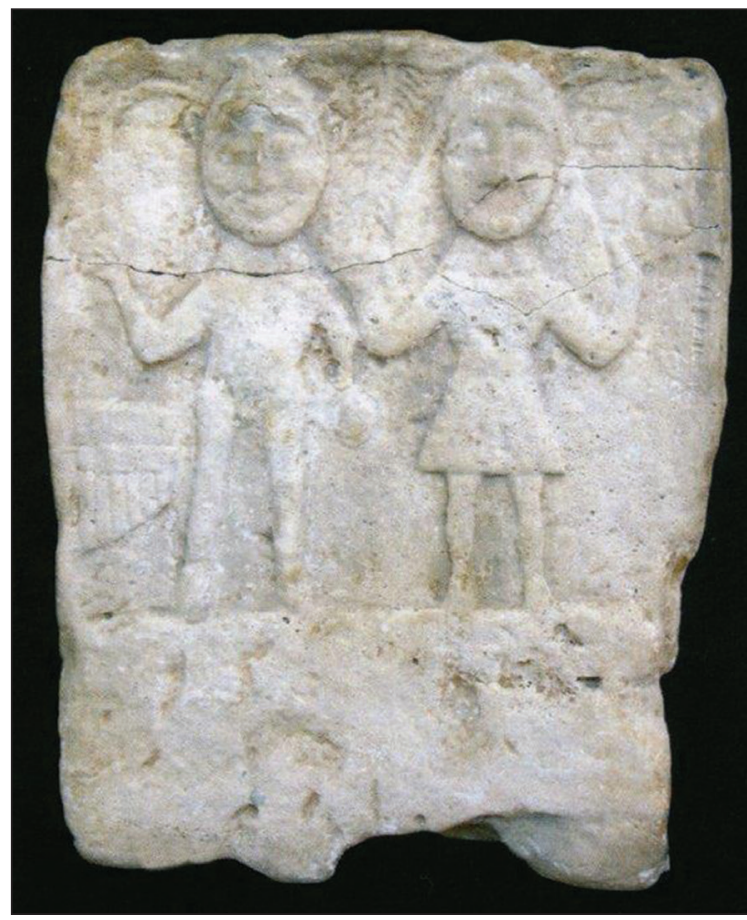

Fig. 17. Silvanus and Diana, Opačići, Bosnia and Herzegovina

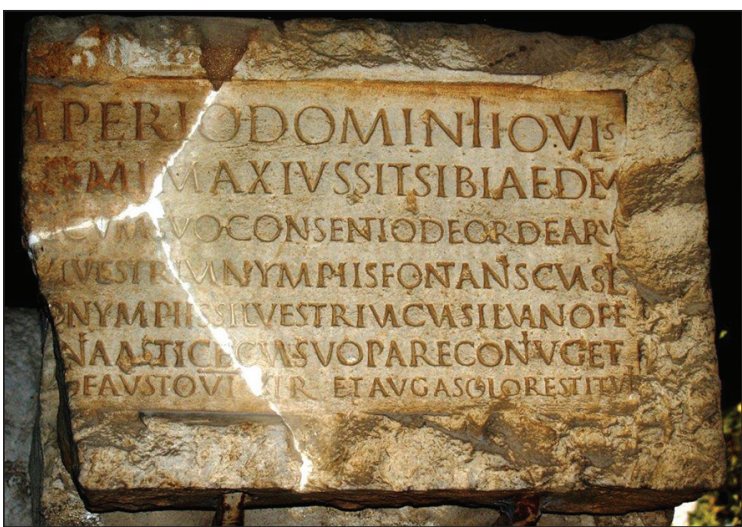

Fig. 18. Klis the epigraph mentioning Jupiter' consentio deorum dearumque silvestrium

was adopted into the official Roman religion. Silvanus and the Nymphs, as a local system, were adopted and became part of Jupiter's religion. Jupiter's temple near Klis is dedicated to Jupiter, along with other Roman gods and goddesses. Each group of Nymphs had their own Silvanus. In this case, one Silvanus was the leader of the Nymphae Fontanae, and the other was the leader of the Nymphae Silvestres, with both groups as part of the consentio deorum dearumque silvestrium. That means that Silvanus had his indigenous pantheon which was included in Jupiter's system by means of (adoptio), thus this local thiasos became a part of Roman religion. ${ }^{51}$ This was normal procedure for the interpretatio romana. An epigraph from Salona mentions only the Consentio deorum without any other specification. ${ }^{52}$ It not very probable that there is any other consentio except, as mentioned, Jupiter's. In this context, it is necessary to emphasize that the temple was erected by Jupiter's decree.

This form of adoption (consentio) into Roman religion is confirmed by a relief depicting Silvanus, three Nymphs and Jupiter from Karakašica near Aequum (now in the Arhaeological $\mathrm{Mu}$ seum of the Franciscan monastery in Sinj). ${ }^{53}$ The group of Nymphs is between Jupiter on the right and Silvanus on the left side (Fig. 19), who were iconographically represented as leaders of Nymphs. However, on the Klis inscription, two Silvani who had their own group of Nymphs

\footnotetext{
${ }^{51}$ About adoptio cfr. Heinzmann 2012, 126-128.

${ }^{52}$ CIL III 1935 . This consentio very likely consisted of Jupiter and the two corresponding Silvani groups.

${ }^{53}$ Rendić-Miočević 1989, tab. LXXX; Cambi 2005, 46, Sl. 53.
} 


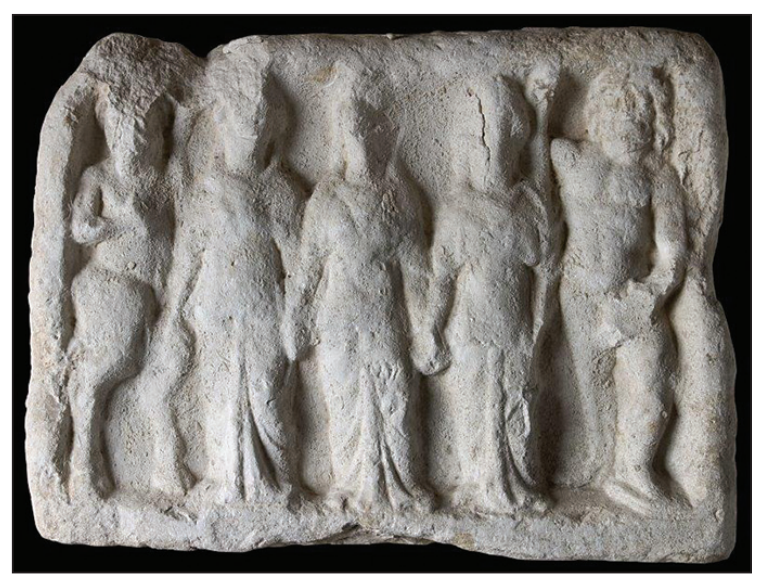

Fig. 19. Silvanuns, Nymphs and Jupiter, Karakašica

were mentioned. One Silvanus is the leader of the Nymphae Silvestres while the other is the head of the Nymphae Fontanae. The two Silvani with their groups of Nymphs (the first group consisting of two and the second of three Nymphs) with different attributes (reeds in the hands of the first, and a tree in hands of the second group) appear only on the relief from Carevo Polje near Jajce in Bosnia (Fig. 20). ${ }^{54}$ Both of them are usually portrayed with a syrinx and pastor's staff (pedum). Both of them are iconographically identical. The idea of two divine groups probably existed in the imagination of the indigenous people (the two Silvani as brothers who lead their own Nymphs). This rare relief clarifies and verifies the inscription from Klis. So the Klis inscription and the Carevo Polje relief prove that the two Silvani and the two groups of Nymphs formed the essence of the natural cyclic religion of the Delmatae. Together with the Roman gods Mercurius, Hercules and Diana, Silvanus was depicted on the relief from Danilo in the Dalmatian hinterland thus confirming their adoption into the Roman religious system (Fig. 21). ${ }^{55}$

Silvanus had several epithets: Silvester, Domesticus, Messor, Cohortalis etc. All of them reveal a different cult character of Silvanus which belonged to his original properties. However, the

\footnotetext{
${ }^{54}$ Paškvalin 1964, 151; Rendić-Miočević 1989, 515-516, tab. LXXXVIII.

55 Abramić 1928-29, 49-54, tab. IV, 1; Rendić-Miočević 1989, 494, tab. LXXXV, 2; Gunjača 1968-69, (Split 1977), 177-183, Sl. 1, 2; Medini 1983, 20-25, Sl. 1; Lipovac Vrkljan / Miletić 1999-2000, 155-164, Sl. 3. This relief is evidence for the acceptance of Silvanus in the religious society of official Roman gods.
}

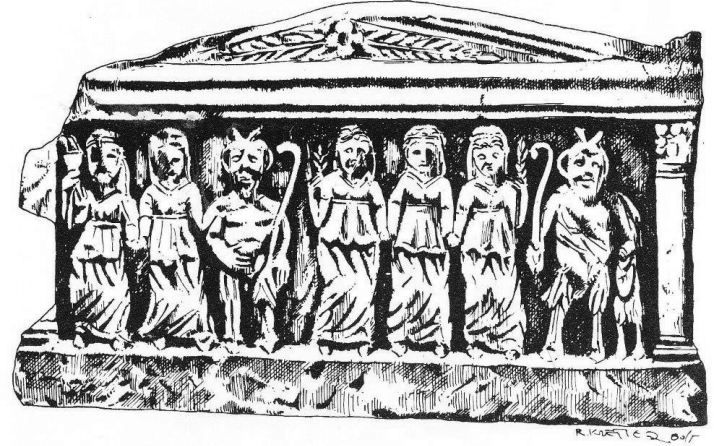

Fig. 20. Two Silvani and two groups of Nymphae, Carevo polje near Jajce

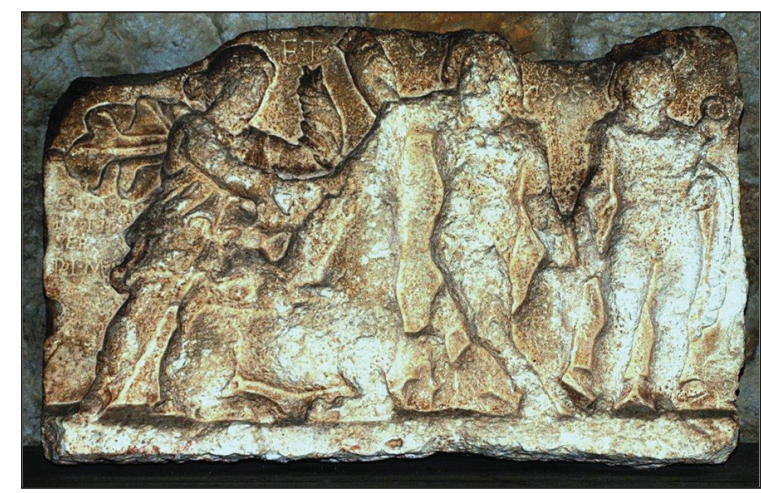

Fig. 21. Diana, Silvanus and Mercury, Danilo Gornje

most numerous reliefs and epigraphs bear the epithet Augustus. Obviously, this last one was the link between the indigenous religion and the emperor, as well as the Roman official religion, and serve as further evidence of the Romanization of the Silvanus religion.

A epigraph specimen in honor of an emperor (Trajan) comes from Salona (Fig. 22). ${ }^{56}$ The inscription was a lintel of a temple constructed in honor of Silvanus for the emperor's rescue. It is very significant that the location for the temple was given by the town council. Two private persons built the temple from its foundations and connected it to the water conduit. Obviously the water was necessary for their rituals. Silvanus

\footnotetext{
56 The inscription (CIL III 8684); Šašel Kos 1994, 205, no 4 runs as follows:

Silvano Avg(usto) Sac(rum) voto suscepto pro salvte Imp(eratoris) Caesaris Nervae Traiani optimi Aug(usti) Ger(amici) Dacici N(umero) II Trophimus Ser(vus) (et) Amandianus dispens(ator) a solo fecit et aquam induxit 1 (ocus) $d$ (atus) d(ecreto) $\mathrm{d}$ (ecurionum)
} 


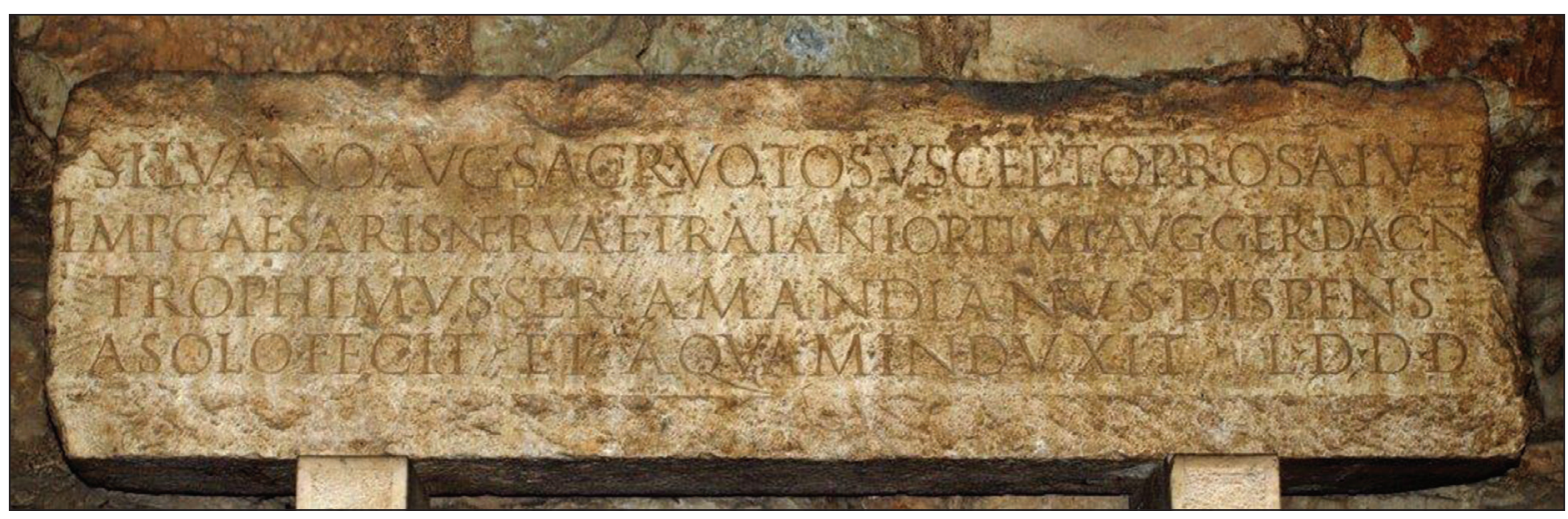

Fig. 22. The lintel of Silvanus' sanctuary Salona

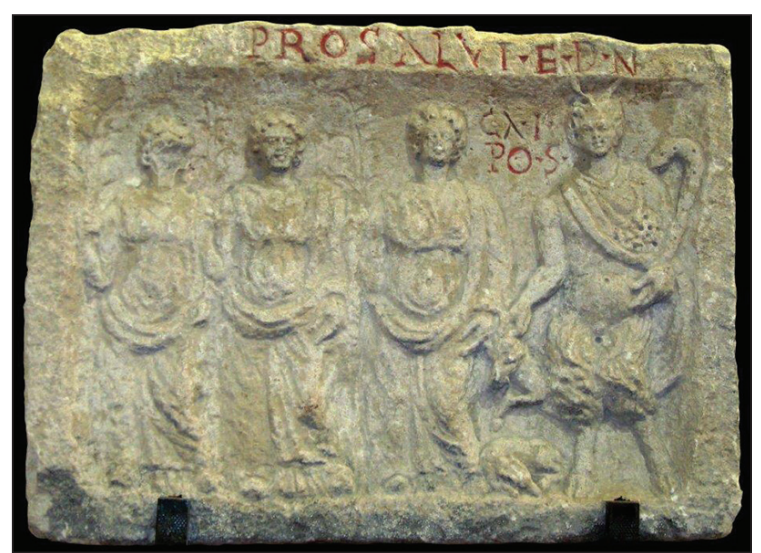

Fig. 23. Silvanus and Nymphae relief from Geremia palace. Now in Avignon

has the attribute Augustus indicating a link to the emperors. ${ }^{57}$

A relief of Silvanus and Nymphs was published by R. Adam. ${ }^{58}$ It was built up in the house Geremia in the vicinity of Diocletian's palace. This relief is kept now in the Calvet Museum in Avignon (Fig. 23). ${ }^{59}$ Silvanus displays the standard iconographic characteristics and Nymphae Fontanae are characterized by reeds. The iconography is standard, but the epigraph is extremely important. In the Adam publication the inscription was not visible, but the picture clearly shows the inscription: ... PRO SALVTE D(omini) $\mathrm{N}$ (ostri) GAI POS(uit). Who was dominus nos-

\footnotetext{
${ }^{57}$ This about cfr. Tassaux 1997, 77-84.

${ }^{58}$ Adam 1764, Pl. LIV. This relief was published later in CIL III 1974. It was given to Museo Nani in Venice. Later the whole collection was sold to Avignon.

${ }^{59}$ For the photo of the relief many thanks goes to RendićMiočević, ex director of the Archaeological Museum in Zagreb. The photo was shot by the curator of the same Museum I. Radman Livaja in Avignon.
}

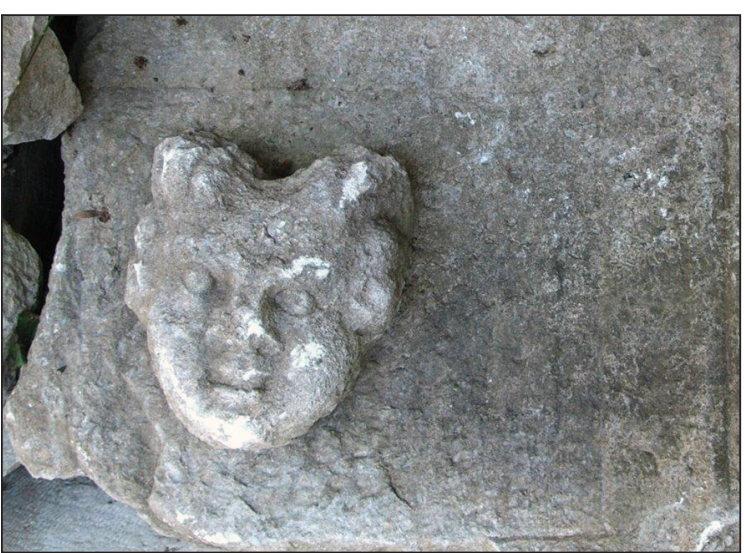

Fig. 24. The Silvanus mask in the coffered ceiling of Diocletian's palace

ter Gaius? The only possibility is that this modest relief was a pious, almost familiar dedication for the salvation of the emperor: Gaius Valerius Aurelius Diocletianus since he was the only emperor to bear the praenomen Gaius after the appearance of the formula dominus noster, in the $3^{\text {rd }}$ century AD. ${ }^{60}$ This relief is also evidence of the presence of the late cult of Silvanus in Dalmatia. The head of a young Silvanus with ram's horns in the coffered ceiling from Diocletian's palace is also evidence for the significance of Silvanus cult in the epoch of the tetrarchy (Fig. 24). ${ }^{61}$ The formula pro salute was a form very often used for emperors and high-ranking officers. In this case, it was likely used to express danger or the illness

\footnotetext{
${ }^{60}$ Demandt 2007 (Neue Auflage), 260. For the first time the title "d. n." appeared in Hadrian's period, but normally after Alexander Severus.

${ }^{61}$ Cambi 2013, 26, Fig. 15.
} 


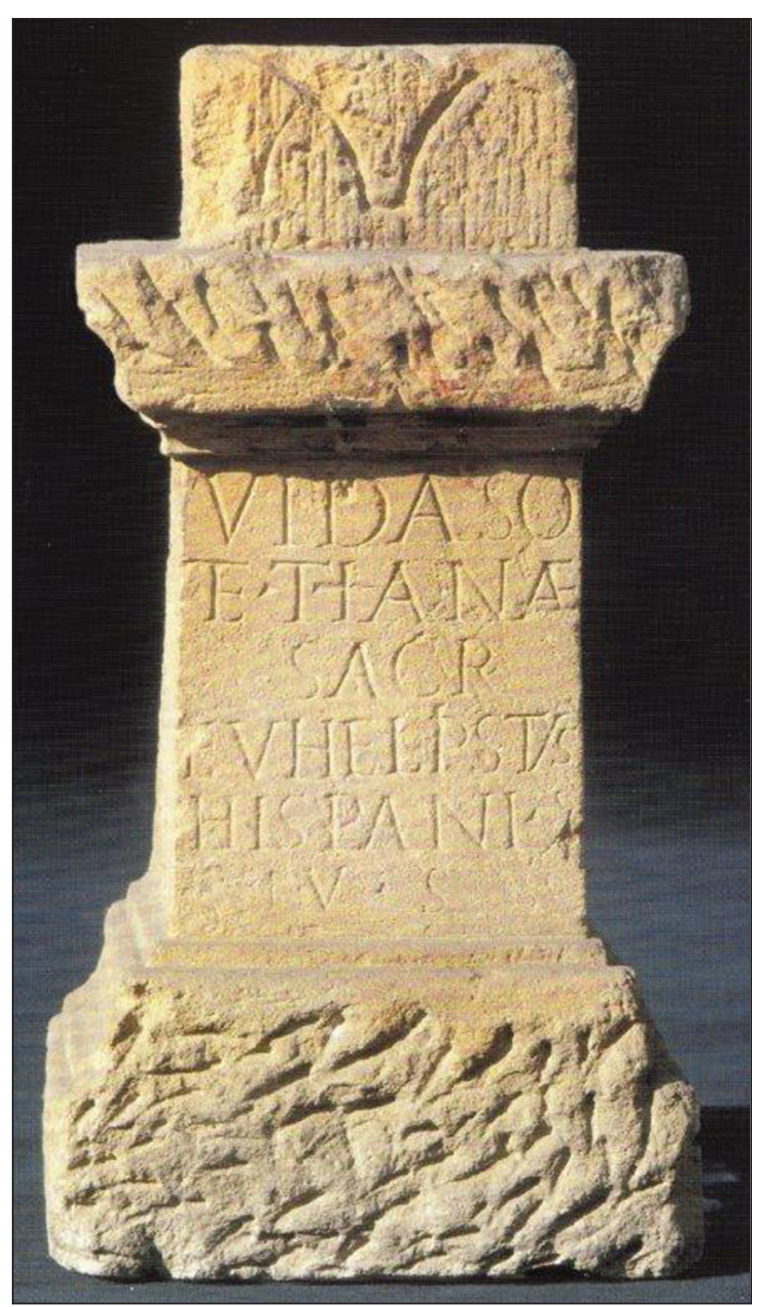

Fig. 25. Altar dedicated to Vidasus and Thana, Topusko

of the emperor. ${ }^{62}$ According to existing evidence, the cult of Silvanus disappeared after the early $4^{\text {th }}$ century.

So these reliefs and epithets reflect the process of how the Dalmatean pantheon was incorporated into the Roman religious system. This developed religious system of the Delmatae was not easily conveyed into official religion, so it was adopted (adoptio) and included within consentio of dei deaeque silvestres. This is the method of unification for the whole system, and not only a single god. Thus we can say that the Dalmatean and Roman religions became unified. The Ro-

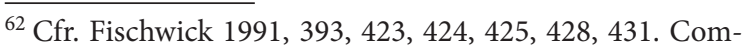
pare also Turcan 1978, 1056-1059 and Jinyu Lin 2009, 258, 259. It is true that the salvation of all citizens might be guaranteed only by the safe government of a safe emperor.
}

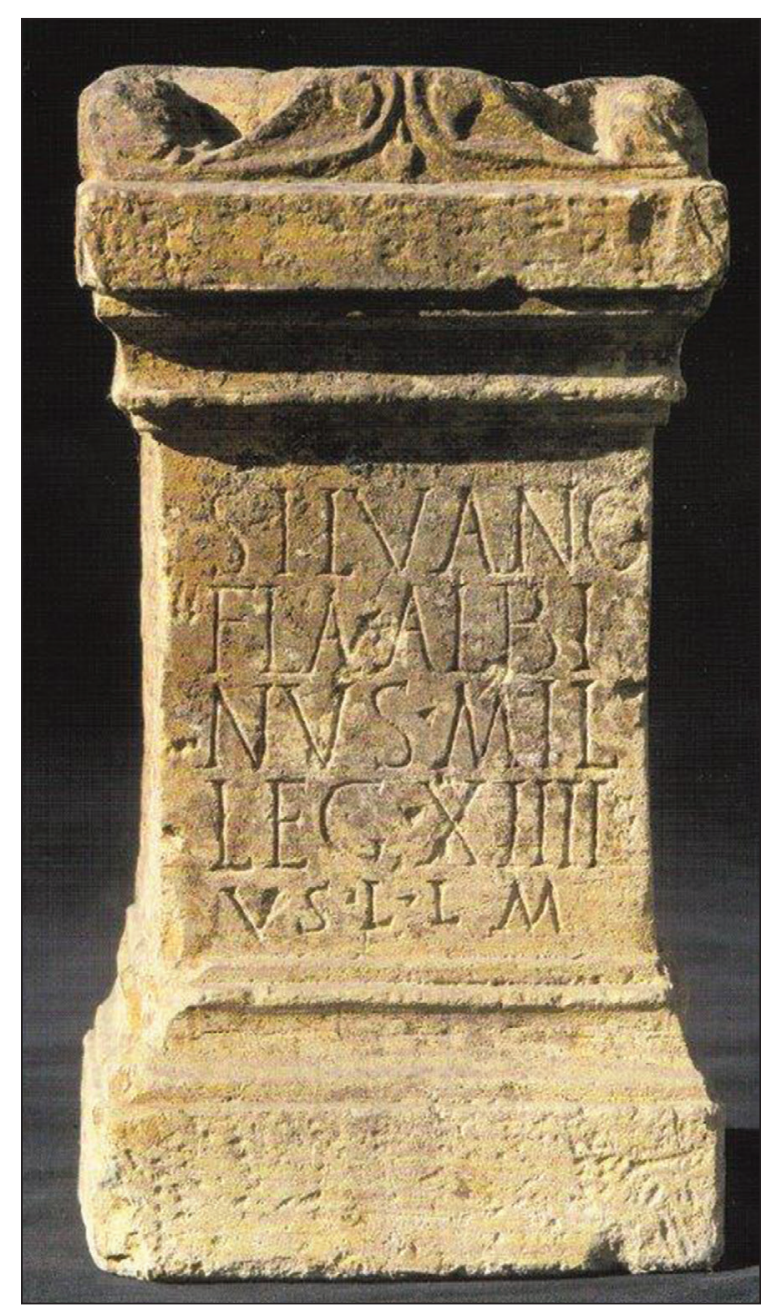

Fig. 26. Altar dedicated to Silvanus, Topusko

manization process was finished during the middle principate period.

There is series of reliefs of Silvanus and Nymphs, of which the latter aren't attributed. Thus it is impossible to decipher which kind of Nymphs they belonged to, but they could represent both natural cycles. The iconographic characteristics and epigraphic evidence of Silvanus and the Nymphs, points to a developed indigenous system of religion, which, according to statistics, must have its origin in central Dalmatia. There are more than a hundred epigraphs and reliefs in the Delmatae area. ${ }^{63}$ This statistic serves as substantial evidence that the Silvanus,

\footnotetext{
${ }^{63}$ Matijašić / Tassaux 2000, 81-117, Fig. on p. 78. The survey on pages 105-112 (altogether 89 examples). But there are at least 15 more epigraphs or reliefs which were not registered, or are new finds.
} 

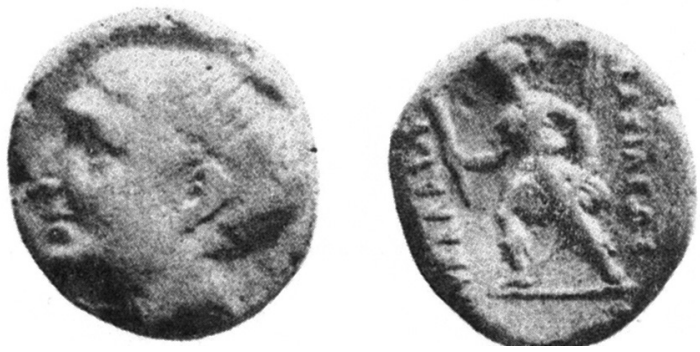

Fig. 27. Silver coin of Ballaios

Nymphae and Diana religions might have begun in this region.

Is it possible to discover the Delmatean name of Silvanus? A. Mayer tried to make a linguistic link between several altars dedicated to Silvanus and Diana found at Topusko (Ad Fines or Quadratum) on the border of Roman Dalmatia and Pannonia. ${ }^{64}$ The altars were dedicated to the gods Vidassus and Thana (Fig. 25), as well as to Silvanus (Fig. 26). Since salutary hot springs were already known at Topusko in the Roman period, these gods were very likely linked to hot water springs. There are, however, differing opinions as far as the religious character of Vidassus and Thana is concerned. ${ }^{65}$ Whether these are indigenous names for Silvanus or Diana is not quite certain, but it is very enticing to connect them to Silvanus, since a similar altar was dedicated to this god. ${ }^{66}$ The latter inscription belongs to the final stage of Romanization. Vidasus and Thana might be connected with Silvanus and Diana, but only on the restricted area of Topusko. An inscription from Lika shows that Silvanus' religion was known on the territory of the Japodes. ${ }^{67}$ The influence of Silvanus' religion has also been observed in other parts of Illyricum. All of them, in my opinion, were a result of religious influence

\footnotetext{
${ }^{64}$ The name is preserved on 4 altars together with Thana (CIL III 3941, 10819=14354, 23), cfr also Hoffiler / Sarja 1938, no 516, 517, 518; Mayer 1943, 187-191; Mayer 1957, 359-360, s. v. Vidasus.

${ }^{65}$ Vidasus and Thana as the healer-god pair of the hot springs, which are abundant in Topusko cfr. Kuntić 2005, 329-351. Silvanus is not known as healer but he appears as savior, especially when endangered emperors are in question. Nymphae Fontanae with shells are the numina of such sulphur and hot springs.

${ }^{66}$ Sanader 2001, 113-118, Fig. on p. 115.

${ }^{67}$ Medini 1975, 87-88.
}

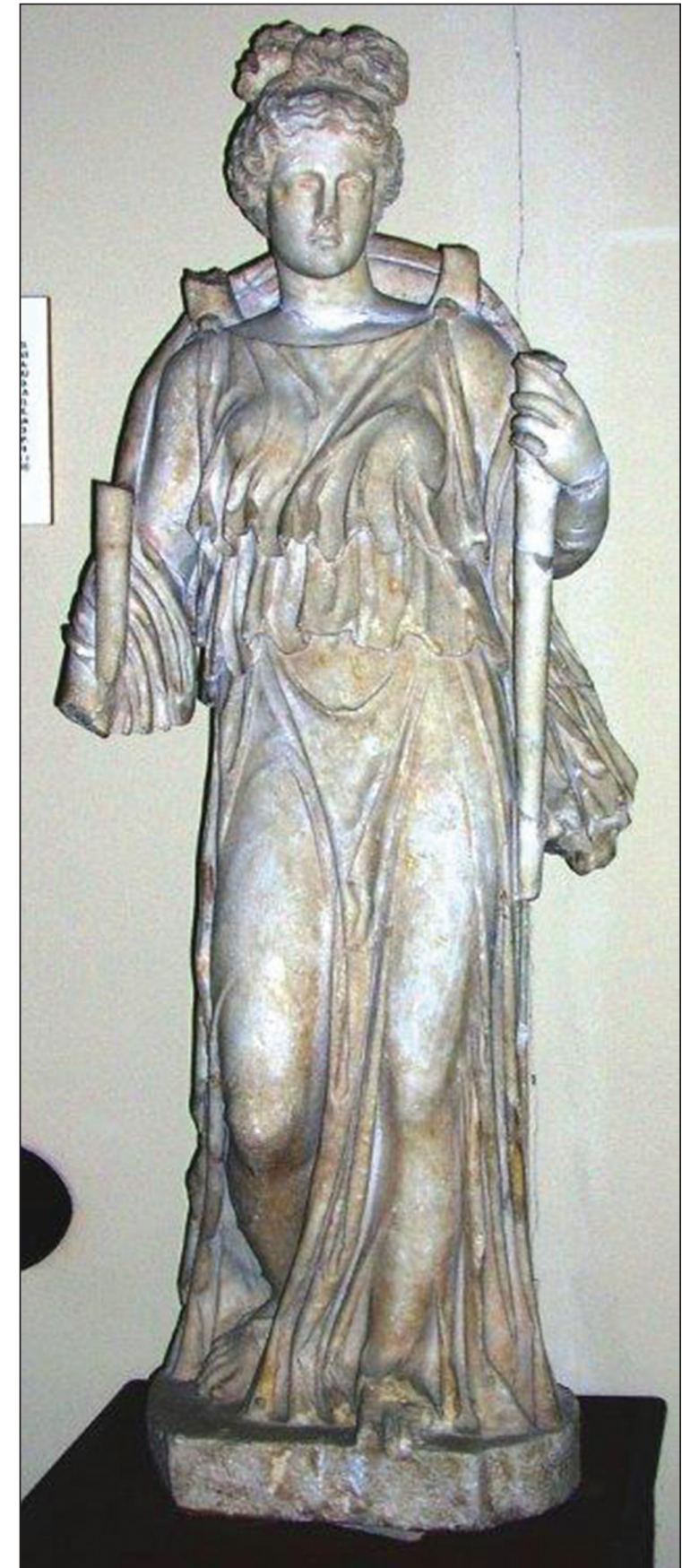

Fig. 28. Diana Lucifera with torches. Archaeological Museum of Franciscan Monastery at Sinj

from the central part of the Roman province of Dalmatia. ${ }^{68}$

Were there other local gods or divine creatures in central Dalmatia except Silvanus, Diana and the Nymphs? There is only slight evidence for such divinities, but there are more local gods

\footnotetext{
${ }^{68}$ About Silvanus in Dardania, Upper Moesia cfr. Mirdita $2007,45-46,170$
} 
such as: Tadenus (syncretised with Apollo), ${ }^{69}$ Talanso ${ }^{70}$ Tato $^{71}$ (Illyrian deus patrius), and Armatus $^{72}$ (probably the translatio of the Delmatean war god of an unknown name, a kind of Roman $\mathrm{Mars}^{73}$ ). An altar, dedicated to Talanso, an unknown local god, was discovered in a village on Livanjsko polje near Livno, which belonged to the original heart of the Delmatean territory. Curiously, the altar was dedicated by Delmatean sailors (classiciani), probably after their discharge from military service. So such a divinity might be linked with water or even the sea.

Diana, together with Silvanus and the Nymphs, was rarely recorded in inscriptions and reliefs to the south of Narona, even though this very important ancient town was close to Delmatean territory. As far as I know, only one such inscription was found around Narona, ${ }^{74}$ so we can safely conclude that this area did not have a close religious relationship with the Delmatean territory.

A female goddess, very similar to the Greek Arthemis or Roman Diana, without Nymphs, evidently prevailed in southern Dalmatia, either on the littoral or in the hinterland. This goddess also didn't reveal a consistent and complex religious system. The Arthemis cult in southern Dalmatia is confirmed by her image on the obverse of the coins of Illyrian king Ballaios circa 167 BC-135 BC, i. e. before stronger Roman penetration (Fig. 26). The silver and bronze coins were found in large quantities in southern and central Dalmatia. ${ }^{75}$ The silver specimens were rare, but mostly very fine, especially the portrait of the king. ${ }^{76}$ The king wanted to depict the main goddess of his territory on the reverses on all coin emissions. This goddess, dressed in a short tunic like on Ballaios' coins, is shown walking with torches.

\footnotetext{
${ }^{69}$ CIL III 13868; Marić 1933, 21-22.

${ }^{70}$ Mayer 1957, 328. This name is preserved on an altar from Livno. It was found before the World War II. It was lost long ago in the Archaeological Museum of Split, but it appeared during a new revision of stone material (thanks to the curator Mario Radaljac). Mayer thought that Talanso is the name of a genius.

${ }^{71}$ Suić 1996, 129-137.

${ }^{72}$ Marić 1933, 28. Two altars with this god's name were found in the vicinity of Deleminium (Županjac).

${ }^{73}$ About translatio cfr. Heinzmann 2012, 120-126.

${ }^{74}$ CIL III 1773.

${ }^{75}$ Brunšmid 1898, 88-98, Pl. VI-VII, Marović 1988, 81-145, Pl. 81-145, Pl. XIV-XXII.

${ }^{76}$ Cambi 2000, 24-26, Pl. 5, figs 12-15.
}

Diana's iconography with torches is also attested to in the central Dalmatia (Aequum), only several centuries later, since such a statue is preserved in the Archaeological Museum of the Franciscan Monastery Museum at Sinj (Fig. 27). ${ }^{77}$ This statue was probably imported from Asia Minor to Dalmatia in the $3^{\text {rd }}$ century AD. But such iconography was familiar to the local people, and is likely the reason for the commission of such kind of a statue.

Significantly, a very important temple, although in the Roman period, was dedicated to Diana in Doclea (the centre of Illyrian Docleatae), which previously belonged to the kingdom of Ballaios. ${ }^{78}$ The Illyrian god Medaurus or Madaurus was revered in the town of Rhisinium (Risan in the Kotor Bay). ${ }^{79}$ This cult is mentioned in several locations where Illyrian soldiers or sailors were stationed. Medaurus iconography is quite different from that of other gods known in Dalmatia. He was depicted as a horseman and warrior. According to epigraphs or historical sources, the god was a healer. His iconography seems to be far removed from such characterization. However, Medaurus might be the rescue god who saves lives from diseases, and not only those of soldiers but other people as well. In this sense Medaurus is linked with Silvanus, but their depictions were quite different.

There are different points of opinions concerning the Illyrian pantheon. Many scholars proposed that the Illyirians did not a developed enough cosmology that could offer a base for their religious practices, unlike the Celts, Thracians or Schytians ${ }^{80}$ In my opinion, this is not quite correct. This assertion is certainly wrong when the Delmatae are in question. These central Dalmatian people had an obviously developed system of religion, which was soon melded with the official Roman religion, as I tried to show here. Jupiter's consentio deorum dearumque silvestrium was a substantive liturgical part of Jupiter's religion, and was worshipped not only by local peoples

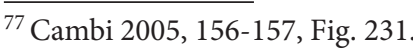

${ }^{78}$ Sticotti / Jelić / Iveković 1913, 80-98. Pl. 47 (the bust of Diana in the gable).

79 Marić 1913, 23-26; Rendić-Miočević 1989, 523-530; Cambi 1997, 819.

${ }^{80}$ Cfr. Wilkes 1996, (2 ${ }^{\text {nd }}$ ed.), 244-247; Cfr. also Ferri 2012, 135-137. Seems that Zequo 1995 (the citation according to N. Ferri) speaks on the Illyrian pantheon.
} 
but also by colonists and other newcomers from other parts of the Roman Empire.

\section{Rezime}

\section{Romanizacija zapadnog Ilirika. Religijski aspekt}

Nema jedinstvenog sustava religija na ilirskim područjima. Većina narodnosno i povijesno afirmiranih etnija imaju svoja vlastita međusobno znatno različita božanstva, a neki i razvijenije sustave. Tipičan primjer su Liburni i Delmati. Liburni su imali različita lokalna božanstva u najvažnijim naseljima (Nedinum, Corinum Asseria, Aenona itd.). Zajednička im je karakteristika da su to samo ženska božanstva koja se po vjerskom i ikonografskom sadržaju međusobno razlikuju. Po tome su Liburni srodni Histrima. Naprotiv, južni susjedni narod - Delmati imaju drugačiji, ali najrazvijeniji religijski sustav u kojemu su Silvan i Dijana glavna božanstva i koji je nastao na središnjem dalmatinskom prostoru u predrimskom razdoblju. Sastavni dijelovi te religije su Nimfe (Fontanae odnosno Silvestrae, tj. vodene, odnosno šumske), koje su pomoćnice i donositeljice različitih prirodnih pogodnosti i bogatstava. Ikonografija se Silvana razvila u Saloni i otud proširila na druge dijelove Dalmacije. U formiranju ikonografije ulogu je odigrao lik grčkog Pana koji je Silvanu samo sličan, ali ne i identičan. Italski Silvan, kako u religijskom sustavu, tako i ikonografskom obliku, nema nikakve veze s religijom u Dalmaciji. Posebno je važan natpis iz Klapavice blizu Klisa koji u rimski religijski sustav (Jupiter) uvodi dva Silvana s dvije različite skupine Nimfa. Dva Silvana s dvije skupine Nimfa javljaju se na reljefu iz Careva polja kod Jajca u Bosni i Hercegovini, što je potvrda klapavičkog natpisa. Nimfe nisu Dijanine nego Silvanove pomoćnice koje djeluju plešući na Silvanovu glazbu (siringa). One također imaju svoju božansku bit (numen). Pojavu Silvanove religije izvan središnjeg dalmatinskog dijela Ilirika treba tumačiti kao utjecaj toga područja. U unutrašnjosti rimske Dalmacije neki su narodi bili pod delmatskim utjecajem, a neki su razvili svoja lokalna božanstva, ali ne i sustave. U južnoj Dalmaciji, kako primorskoj, tako i unutrašnjoj, nema religijskog sustava, a predominira žensko božanstvo (Diana), bez pratnje Nimfa.

\section{Bibliography}

Abramić, M. 1928-29, Nekoliko skulptura antiknih božanstava, Vjesnik za arheologiju i historiju dalmatinsku L, 1928-29, 49 -54.

Abramić, M. 1940, Archäologische Forschung in Jugoslawien, Bericht über den VI Internationalen Kongress für Archäologie, Berlin 21-26. August 1939, Berlin 1940, 166-180.

Abramić, M. 1952, Antike Kopien griechischer Skulpturen in Dalmatien, In: Beiträge zur älteren europäischen Kulturgeschichte, Festschrift für Rudolf Egger I, Klagenfurt 1952, 303-326.

Adam, R. 1764, Ruins of the palace of the Emperor Diocletian at Spalatro in Dalmatia, London 1764.

Alföldi, G. 1969, Die Personennamen der römischen Provinz Dalmatien, Heidelberg 1969.

Ando, C. 2005, Interpretatio Romana, Classical Philology, 100, no 1, 2005, 41-51.

Borgeau, R. 1979, Recherches sur le dieu Pan, Bibliotheca Helvetica Romana XVII, Rome 1979.

Brunšmid, J. 1898, Inschriften und Münzen griechisher Städte Dalmatiens, Wien 1898.

Bulić, F. 1907, Sterro di una Chiesa antica cristiana del VI sec. nella località detta Crikvine a Klapavica nel commune censuario di Klis (Clissa), Bulletino di archeologia e storia dalmata XXX 1907, 101-122.

Cambi, N. 1980, Enonska Venera Anzotika, Diadora 9, 1980, 273-278.

Cambi, N. 1997, "Medaurus". Lexicon Iconographicum Mythologiae Classicae VIII, 1, Zürich-Düsseldorf 1997, 819.

Cambi, N. 1994, Lexicon iconographicum Mythologiae Classicae VII, 1, 1994, 500, s. v. Neptunus Bindus.

Cambi, N. 2000, Imago animi. Antički portret u Hrvatskoj, Split 2000.

Cambi, N. 2005, Kiparstvo rimske Dalmacije, Split 2005.

Cambi, N. 2013, Religija Silvana u rimskoj Dalmaciji, u: Kultovi i mitovi i vjerovanja u Zagori, Zbornik radova sa znanstvenog skupa održanog 14. prosinca 2012. u Unešiću, Split 2013, 15-41.

Demandt, A. 2007, Die Spätantike. Römische Geschichte von Diokletian bis Justinian 284-565 n. Chr, München 2007 (Neue Auflage).

Dorcey, P. 1992, The Cult of Silvanus, Leiden 1992.

Ferguson, J. 1974, The Religions of the Roman Empire, London 1974.

Ferri, N. 2012, Vjerovanja i štovanja bogova u predkršćanskoj Dardaniji, Godišnjak 41, Akademija nauka i umjetnosti Bosne i Hercegovine, Centar za balkanološka ispitivanja, Sarajevo 2012, 135-158.

Ferri, S. 1975, Luci e l' ombre sulla „interpretatio romana", Convegno internazionale Renania Roma- 
na, Atti dei convegni Lincei 23, Roma, 14-16 aprile 1975, Roma 1976, 125-133.

Fischwick, D. 1991, The Imperial Cult in the Latin West. Studies in the Rule Cult of the Western Provinces of the Roman Empire, II, 1, Leiden 1991.

Gimbutas, M. 2007, The Goddesses and Gods of Old Europe. Myths and Cult Images 6500-3500 BC, London 1982 (rep. 2007), 152-196.

Gunjača, Z. 1968-69, Reljef Silvana Messora iz Ridera, Vjesnik za arheologiju i historiju dalmatinsku LXX-LXXI, 1968-69, (Split 1977), 177-183.

Heinzmann, M. 2012, Interpretatio Romana v. s. Translatio Latina. Zu einzelnen Aspekten des Interpretationsverfahrens bei Caesar und Tacitus, Mediterraneo antico. Economie società culturale, XV, 1-2, Roma 2012, 117-142.

Herbig, R. 1949, Pan der griechische Bocksgott, Frankfurt am Main 1949.

Hoffiller, V. / Sarja, B. 1938, Antike Inschriften aus Jugoslawien 1, Agram 1938.

Imamović, E. 1977, Antički kultni i votivni spomenici na području Bosne i Hercegovine, Sarajevo 1977.

Jinyu Lin, R. 2009, Collegia Centenariorum. The Guilds of Textile Dealers in the Roman West, Leiden 2009.

Jurkić, V. 2005, Duhovna kultura antičke Istre, knj. I. Kultovi u procesu romanizacije antičke Istre, Zagreb 2005.

Katičić, R. 1962, Die illyrischen Personennamen in ihrem südöstlichen Verbreitungsgebiet, Živa Antika 12, 1962, 95-120.

Katičić, R. 1963, Das mitteldalmatische Namengebiet. Živa Antika 12, 1963, 255-293.

Katičić, R. 1964, Namengebiete im römischen Dalmatien, Die Sprache 10, 1964, 23-33.

Katičić, R. 1976, Ancient Languages of the Balkans. I-II, Paris 1976.

Katičić R. 2009, Tri starobalkanska „nomina sacra“, u: Illyricum mythologicum, Zagreb 1995, 125-160.

Kukoč, S. 2009, Japodi - fragmenta symbolica, Split 2009.

Kuntić Makvić, B. 2003, Borvo et Damona - Vidasus et Thana: les possibilites de l' analyse comparative, u: Illyrica antiqua ob honorem Duje RendićMiočević. Radovi s međunarodnog skupa o problemima antičke arheologije, Zagreb 6. - 8. XI. 2003, Zagreb 2005, 329-351.

Kurilić, A. 2002, Liburnski antroponimi, Folia onomastica Croatica, 11, Zagreb 2002, 123-148.

Lipovac Vrkljan, G. / Miletić, Ž. 1999-2000, Reljef Dijane iz Ridera, Opuscula Arcaeologica 23-24, 1999-2000, 155-164.

Marić, R. 1933, Antički kultovi u našoj zemlji, Beo$\operatorname{grad} 1933$.
Marović, I. 1988, Novac ilirskog dinasta Baleja (Ballaios) u Arheološkom muzeju u Splitu, VAHD, 81, 1988, 81-145.

Marquardt, N. 1995, Pan in der hellenistischen Kunst und kaiserzeitlichen Plastik, Bonn 1995.

Maršić, D. 1997, Ikonografski tip Nimfa sa školjkama, Vjesnik Arheološkog muzeja Zagreb 3, ser. XXXXXXI 1997.

Matijašić, R. / Tassaux, F. 2000, Liber et Silvanus, u: Les cultes polythéistes dans l' Adriatique romaine, Paris-Bordeaux 2000, 65-117.

Matijašić, R. 2009, Povijest hrvatskih zemalja u antici do cara Dioklecijana, Zagreb 2009.

Mayer, A. 1943, Vidasus, der illyrische Silvanus, Vjesnik Hrvatskog arheološkog društva, 22-23, 1943, 187-191.

Mayer, A. 1957, Die Sprache der alten Illyrer, I, Wien 1957.

Medini, J. 1972, Kultovi u antici na našoj obali, Obavijesti HAD-a 4, br. 2, Zagreb 1972, 34-36.

Medini, J. 1975, Neki aspekti razvoja antičkih religija na području Japoda, u: Arheološka problematika Like. Znanstveni skup Otočac 22-24. IX 1974, Split 1975, 85-94.

Medini, J. 1983, Prilog poznavanju i tumačenju ikonografije božice Dijane u Iliriku, Radovi Filozofskog fakulteta u Zadru 23 (10), 1983, 17-26.

Medini, J. 1984, Autohtoni kultovi u razvoju antičkih religija u rimskoj provinciji Dalmaciji, Dometi 17, br. 5, Rijeka 1984, 7-32.

Medini, J. 1984, Latra - Dea Neditarum, u: Simpozijum „Duhovna kultura Ilira“, Herceg Novi, 4-6. novembra 1982, Posebna izdanja Akademije nauka i umjetnosti Bosne i Hercegovine LVII, Centar za balkanološka ispitivanja 11, Sarajevo 1984, 223243.

Mirdita, Z. 2007, Religija i kultovi Dardanaca i Dardanije u antici, Zagreb 2007.

Nagy, A. 1994, „Silvanus“. Lexicon Mythologicum Iconographiae Classicae VII, 1, Zürich-München 1994, 763-773.

Olujić, B. 2007, Povijest Japoda. Pristup, Zagreb 2007.

Paškvalin, V. 1964, Reljef Silvana i nimfi, Glasnik Zemaljskog muzeja Sarajevo, n. s. XIX, 1964, 151156.

Raunig, B. 2004, Umjetnost i religija prahistorijskih Japoda, Sarajevo 2004.

Rendić-Miočević, A. / Šegvić, M. 1998, Religions and Cults in South Pannonian Regions, In: Religions and Cults in Pannonia, Exhibition at Székesfehérvàr, Csók István Gallery 15 May - 30 September 1996, Székesfehérvàr 1998, 7-11.

Rendić-Miočević, A. 2003, Les traditions autochtones dans les représentations figurées sur le territoire des Dalmates illyriens, Romanisation und Resistenz in Plastik, Architektur und Inschriften der 
Provinzen des Imperium Romanum, Neue Funde und Forschungen, Akten des VII. Internationalen Colloquiums über Probleme des Provinzialrömischen Kunstschaffens Köln 2. bis 6. Mai 2001, Mainz 2003, 408-419.

Rendić-Miočević, D. 1948, Ilirska onomastika, Split 1948.

Rendić-Miočević, D. 1989, Onomastičke studije s teritorija Liburna. Prilozi ilirskoj onomastici, Iliri i antički svijet, Split, 1989, 711-728.

Rendić-Miočević, D. 1989, „Princeps municipi Riditarum“ (Uz novi epigrafski nalaz u Danilu Gornjem - (Rider)), u: Iliri i antički svijet, Ilirološke studije. Povijest - arheologija - umjetnost - numizmatika - onomastika, Split 1989, 872-890.

Rendić-Miočević, D. 1989, Problemi romanizacije Ilira s osobitim obzirom na kultove i onomastiku, u: Iliri i antički svijet, Ilirološke studije. Povijest - arheologija - umjetnost - numizmatika - onomastika, Split 1989, 425-439.

Rendić-Miočević D. 1989, Silvan i njegova kultna zajednica u mitologiji Ilira, Ikonografska studija o spomenicima s teritorija Delmata, Iliri i antički svijet, Split 1989, 461-506.

Rendić-Miočević, D. 1989, Uz jedan novi izvor o kultu ilirskog boga Medaura, u: Iliri i antički svijet, Ilirološka studije, Split 1989, 523-530.

Sanader, M. 2001, Antički gradovi u Hrvatskoj, Zagreb 2001.

Von Schneider, R. 1885, Bericht über eine Reise in Dalmatien, Über bildlichen Denkmäler Dalmatiens, Archäologisch-epigraphisches Mittheilungen aus Österreich-Ungarn IX, 1885, 31-84.

Selem, P. 2005, Quelques indices sur les relations entre les divinités autochtones et orientales en Dalma- tie romaine, in: Illyrica antiqua ob honorem Duje Rendić-Miočević. Radovi s međunarodnog skupa o problemima antičke arheologije, Zagreb 6. - 8 . XI. 2003, Zagreb 2005, 425-431.

Simon, E. 1990, Die Götter der Römer, München 1990.

Sticotti, A. / Jelić, L. / Iveković, Ć. M. 1913, Die Römische Stadt Doclea in Montenegro, Wien 1913.

Suić, M. 1969, Antički Nin (Aenona) i njegovi spomenici. Povijest grada Nina, Zadar 1969, 61-104.

Suić, M. 1996, Tato ilirski Deus patrius, Odabrani radovi iz stare povijesti Hrvatske. Opera selecta, Zadar 1996, 129-137.

Šašel, A. / Šašel, J. (Eds.) 1963, Inscriptiones Latinae: quae in Iugoslavia inter annos MCMXL et MCMLX repertae et editae sunt, Ljubljana 1963.

Šašel Kos, M. 1999, Pre-Roman Divinities of the Eastern Alps and Adriatic, Ljubljana 1999.

Tassaux, F. 1997, Les dieux augustes en Istrie, u: Arheološka istraživanja u Istri, Znanstveni skup Poreč, 22.-26. rujna 1994, Izdanja Hrvatskog arheološkog društva 18, Zagreb 1997, 77-84.

Turcan, R. 1978, Le culte impérial au III ${ }^{\mathrm{e}}$ siècle, Aufstieg und Niedergang der römischen Welt 16, 2, Berlin-New-York 1978, 996-1084.

Wilkes, J. J. 1969, Dalmatia, London 1969.

Wilkes, J. J. 1996, The Illyirians, Oxford and Cambridge (USA) 1996 (sec. ed.).

Wissowa, G. 2007, Interpretatio Romana, Archiv für Religionswissenschaft XIX, Leipzig-Berlin 1918, $1-49$.

Zaninović, M. 2007, Ilirsko pleme Delmati, Šibenik 2007.

Zequo, M. 1995, Panteoni ilir, Tirana 1995 (the quotation according to N. Ferri). 